\title{
Revealing the pace of river landscape evolution during the Quaternary: Recent developments in numerical dating methods
}

\author{
Gilles Rixhon $^{\mathrm{a}, *}$, Rebecca M. Briant ${ }^{\mathrm{b}}$, Stéphane Cordier $^{\mathrm{c}}$, Mathieu Duval ${ }^{\mathrm{d}}$, Anna Jones ${ }^{\mathrm{e}}$, Denis Scholz ${ }^{\mathrm{f}}$ \\ a University of Cologne, Institute of Geography, Zülpicher Str. 45, 50674 Cologne, Germany \\ ${ }^{\mathrm{b}}$ Birkbeck University of London, Department of Geography, Environment and Development Studies, London, UK \\ c University Paris Est Créteil Val de Marne, Department of Geography, Paris, France \\ ${ }^{\mathrm{d}}$ Centro Nacional de Investigación sobre la Evolución Humana (CENIEH), Burgos, Spain \\ e Edge Hill University, Department of Geography, Ormskirk, UK \\ ${ }^{\mathrm{f}}$ University of Mainz, Institut of Geosciences, Mainz, Germany
}

\section{A R T I C L E IN F O}

\section{Article history:}

Received 29 February 2016

Received in revised form 18 July 2016

Accepted 8 August 2016

Available online $\mathrm{xxx}$

Keywords:

Numerical dating method

Fluvial archives

Quaternary

${ }^{14} \mathrm{C}$ dating

Luminescence dating

ESR dating

${ }^{230} \mathrm{Th} / \mathrm{U}$ dating

Terrestrial cosmogenic nuclides dating

\section{A B S T R A C T}

During the last twenty years, several technical developments have considerably intensified the use of numerical dating methods for the Quaternary. The study of fluvial archives has greatly benefited from these enhancements, opening new dating horizons for a range of archives at distinct time scales and thereby providing new insights into previously unanswered questions. In this contribution, we separately present the state of the art of five numerical dating methods that are frequently used in the fluvial context: radiocarbon, Luminescence, Electron Spin Resonance (ESR), ${ }^{230} \mathrm{Th} / \mathrm{U}$ and terrestrial cosmogenic nuclides (TCN) dating. We focus on the major recent developments for each technique that are most relevant for new dating applications in diverse fluvial environments and on explaining these for non-specialists. Therefore, essential information and precautions about sampling strategies in the field and/or laboratory procedures are provided. For each method, new and important implications for chronological reconstructions of Quaternary fluvial landscapes are discussed and, where necessary, exemplified by key case studies. A clear statement of the current technical limitations of these methods is included and forthcoming developments, which might possibly open new horizons for dating fluvial archives in the near future, are summarised.

(C) 2016 Published by Elsevier Ltd

\section{Introduction}

Unravelling processes and rates of long-term landscape evolution, focusing on the evolution of river drainage systems, has been a core topic in the earth surface sciences since Davis (1899) pioneering work more than a century ago. Since then, river terrace sequences and/or related landforms have thus been extensively used as geomorphic markers across the world. However, assigning chronologies to these sequences and related river sediments or landforms has constantly been challenging. Until the late 20th century, this goal was often achieved using diverse methods that provide relative age information on Quaternary fluvial deposits. Such methods included: correlation with the alpine glacial chronology (e.g. Brunnacker et al., 1982), soil chronosequences (e.g. Engel et al., 1996), palaeomagnetism (e.g. Jacobson et al., 1988), clast seismic velocity (e.g. Crook, 1986), weathering rind analysis (e.g. Colman and Pierce, 1981), obsidian hydration (e.g. Adams et al., 1992), amino-acid racemization of terrestrial molluscs (e.g. Bates, 1994) or correlation to Marine Isotope Stages (MIS) via mammalian (e.g. Schreve, 2001) and molluscan (e.g. Preece, 1999) biostratigraphy. Combining these methods often yielded insightful relative chronologies for Quaternary terrace flights (e.g. Knuepfer, 1988; Schreve et al., 2007).

\footnotetext{
${ }^{*}$ Corresponding author.

Email address: grixhon@uni-koeln.de (G. Rixhon)
}

Whilst methodological improvements to some of these techniques have since been achieved (e.g. Penkman et al., 2007 for amino-acid racemization), in most instances, relative dating methods have been progressively supplemented by dating methods delivering abselute numerical ages over the last two or three decades. With the exception of radiocarbon dating, which has been applied since Libby's seminal paper (Libby et al., 1949), the development of most of these geochronometers occurred in relation to major theoretical and/or technical improvements in the late 20th century. For instance, although cosmic rays were discovered in 1912 by the Nobel laureate Victor Hess, only the development of accelerator mass spectrometers (AMS) in the 1980s enabled measurements of cosmogenic nuclide concentrations (e.g. Klein et al., 1982) and thus their use as a geochronometer (e.g. Nishiizumi et al., 1986). Likewise, Electron Spin Resonance (ESR) spectroscopy, already outlined in the mid 1930s (Gorter, 1936), was first successfully applied as a dating tool only 40 years later (Ikeya, 1975).

In the framework of this FLAG (Fluvial Archives Goup) special issue, we present and discuss the recent major dating advances offered by modern numerical methods in diverse fluvial environments. Five methods are discussed: radiocarbon, Luminescence, Electron Spin Resonance, ${ }^{230} \mathrm{Th} / \mathrm{U}$ and terrestrial cosmogenic nuclide $(\mathrm{TCN})$ dating. They were specifically selected amongst the array of Quaternary dating methods because (i) they are commonly used in the fluvial context, (ii) they have all experienced major theoretical and/or 
technical developments during recent decades, (iii) they require different dateable material and thereby may also yield information about a wide range of fluvial processes and environments, (iv) they have different time ranges of application, but altogether, span the last million years (Fig. 1). Detailing all theoretical principles of the individual techniques is beyond the scope of this contribution. Instead, the focus is on relevant major technical developments and how these enabled new dating applications for different kinds of fluvial archives in distinct settings. The pathways of dateable material within fluvial systems are detailed in Fig. 2. Fundamental information and pre- cautions about sampling strategies in the field and/or laboratory procedures are also provided. Whilst these are well known by geochronologists, they have not often been published and need therefore to be clarified to non-specialists who intent to collect samples for dating. For each method, new and important implications for chronological reconstructions of Quaternary fluvial landscapes are also discussed and, if necessary, exemplified. Case studies published in outputs related to former FLAG activities and using one (or more) of these dating method(s) are listed in Table 1. Current technical limitations and probable forthcoming developments are also addressed.

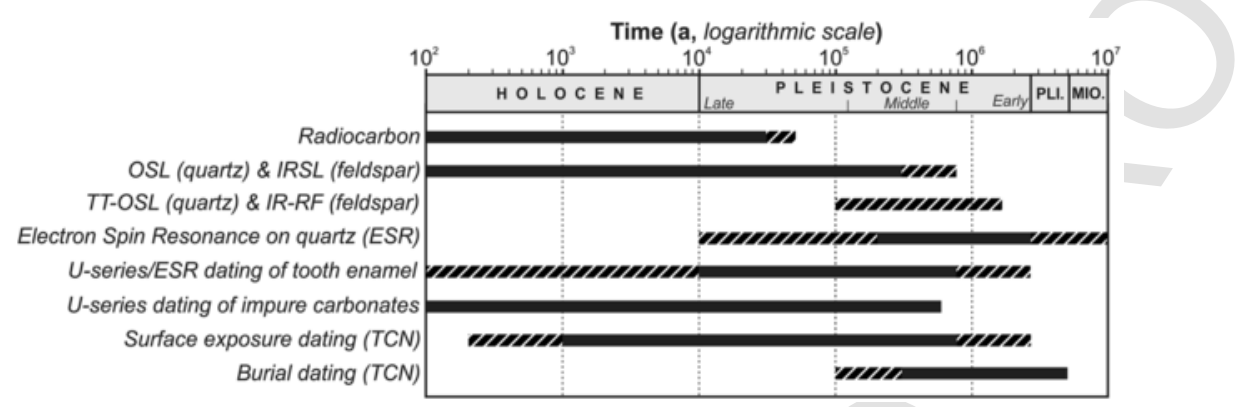

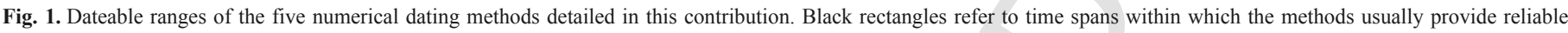

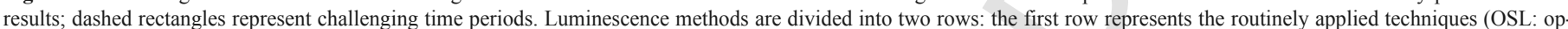

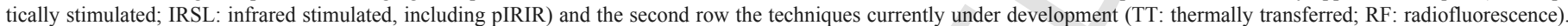

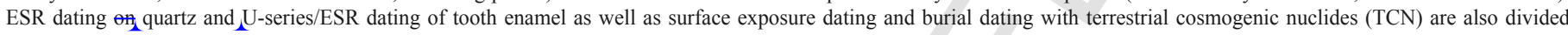
because of the different dating principles.

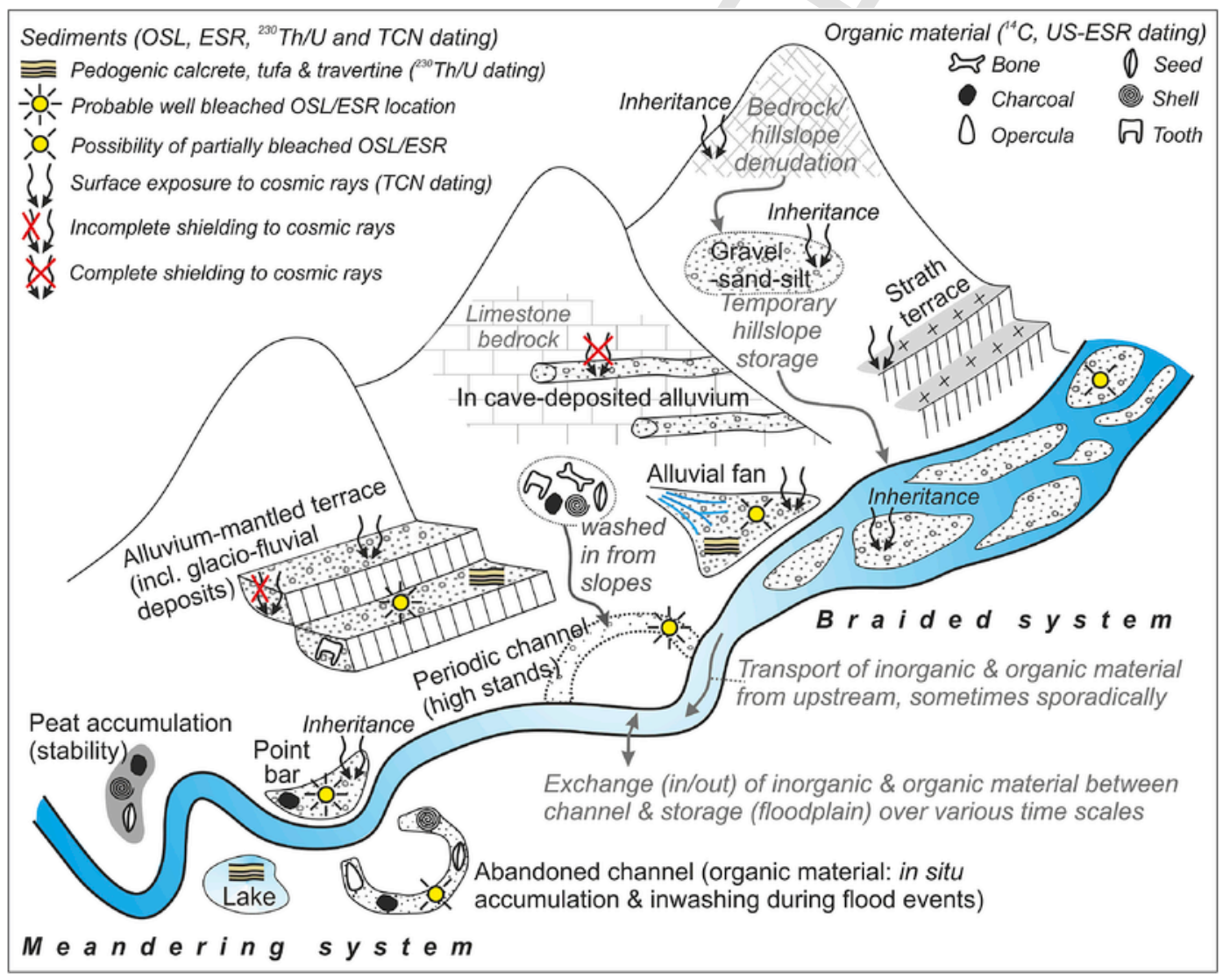

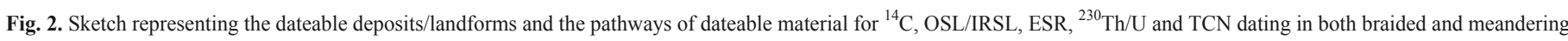

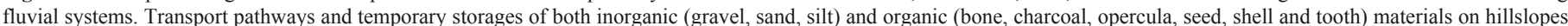
and in the fluvial system are also represented. 
Table 1

Case studies published in outcomes relative to former FLAG activities using one (or more) numerical dating methods detailed in the text.

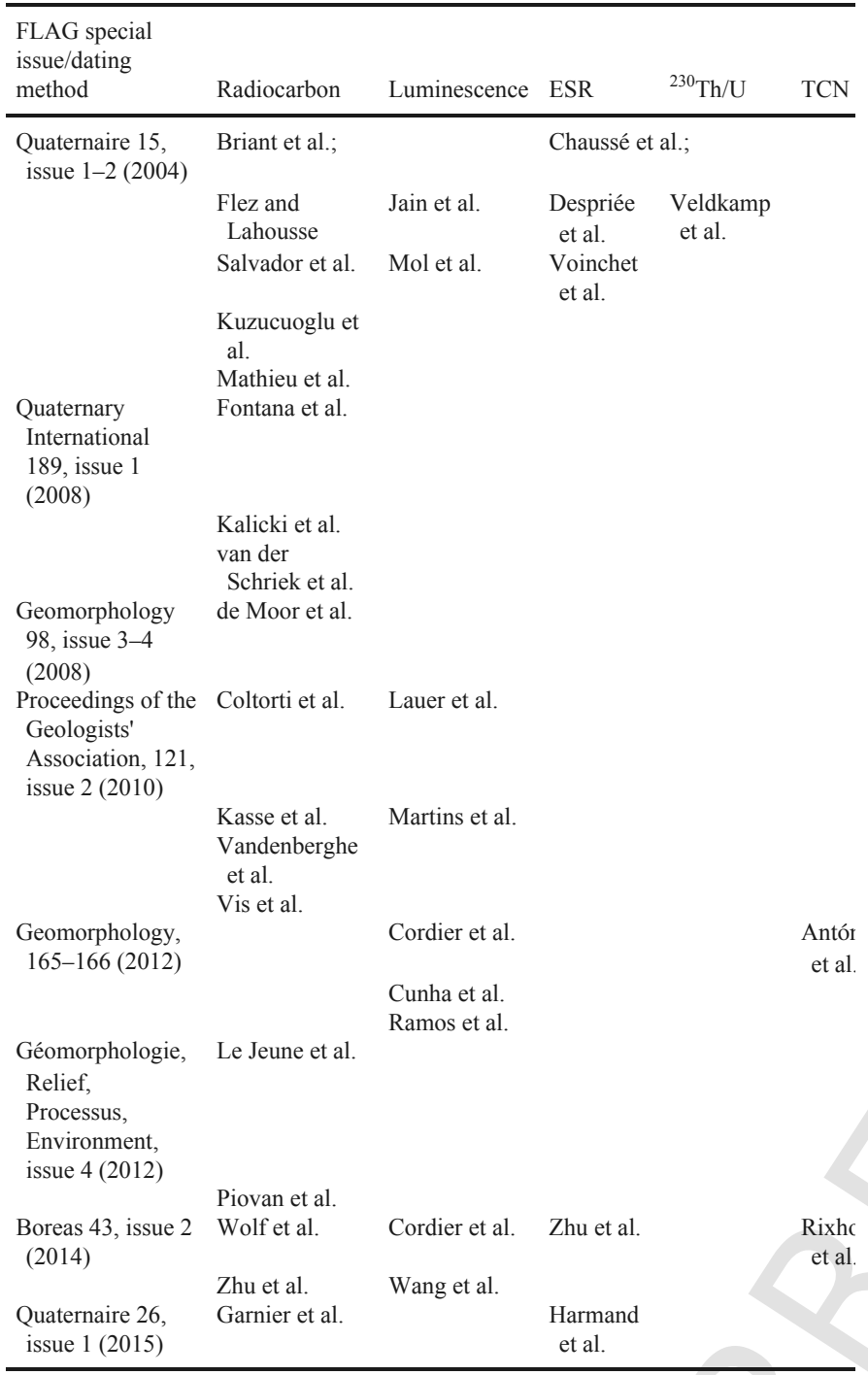

\section{Radiocarbon dating of fluvial deposits}

Radiocarbon dating has been a common method applied to fluvial deposits in those settings where organic material is readily preserved within sequences, i.e. partially or fully waterlogged parts of the floodplain system, including channels and overbank deposits (Fig. 2 ). As a technique it has contributed significantly to understanding key questions, both about palaeoenvironmental information contained within fluvial deposits (e.g. Kasse et al., 1995) and about periods of river activity (e.g. Macklin et al., 2005). The accuracy with which age estimates can be gained from ever smaller samples has improved significantly over the 60-70 years since the first development of the technique. This is partly due to the increasingly routine use of accelerator mass spectrometry (AMS) measurements of smaller samples ( $\sim 1 \mathrm{mg}$ in some cases, Ruff et al., 2010, but more robustly 5-6 mg, Brock et al., 2010). Another important development has been the significant international cooperation involved in calibrating radiocarbon measurements against independent annually-resolved records to account for natural variability in the concentration of atmospheric ${ }^{14} \mathrm{C}$, culminating most recently in the IntCal13 dataset (Reimer et al., 2013).

The ${ }^{14} \mathrm{C}$ dating method can be applied to any material that contains carbon. This includes: cellulose-containing materials (wood, seeds, plant remains), charcoal and charred material, carbonates (including corals, foraminifera, shells), collagen-containing materials (bone, tooth, antler, ivory), hair, and bulk sediment. Many of these are found within fluvial deposits in more temperate environments, where preservation conditions are favourable, but not all are in situ (Fig. 2). Therefore, when considering the radiocarbon dating of fluvial deposits, we need to consider the issue of provenance and reworking. In addition, calibration, reservoir effects and appropriate pretreatments are also relevant to fluvial archives in lakes, but reviewed elsewhere (Brauer et al., 2014).

All present-day carbon-bearing material contains three naturally occurring carbon isotopes. Of these, ${ }^{14} \mathrm{C}$ is radioactive, with a half life of $5730 \pm 40$ years (Godwin, 1962). The source of this ${ }^{14} \mathrm{C}$ is cosmic ray activity in the atmosphere. This enters the global carbon cycle when it is oxidised to $\mathrm{CO}_{2}$, and concentrations are very low compared to ${ }^{12} \mathrm{C}$ and ${ }^{13} \mathrm{C}$. Conventional radiocarbon ages are calculated from measured concentrations of ${ }^{14} \mathrm{C}$, using either beta counting methods or, meanwhile more commonly, AMS. To allow consistency with earlier analyses, these are reported using the original Libby half life of 5568 years (e.g. Stuiver and Polach, 1977; Reimer et al., 2004). They are also corrected for fractionation processes that occur during measurement, as described by Brauer et al. (2014). Because of the multiple stages at which differences can occur within the calculation of a radiocarbon age, they should be reported in detail according to the conventions described by Millard (2014).

\subsection{Provenance and reworking of radiocarbon samples in the fluvial environment}

A feature of fluvial systems is the wide range of depositional environments which may be found within a single catchment, including, for instance, river channel, floodplain and floodbasin deposits. These differ in frequency of depositional events, deposited grain sizes and likely presence of in situ organics (Fig. 2). The nature and rate of fluvial activity within a reach determine the spatial distribution of depositional environments and their preservation within the alluvial record (Lewin and Macklin, 2003). The depositional context of a radiocarbon-dated sample determines its suitability for answering questions about the timing of events within a fluvial system. Where possible, a distinction should therefore be made between radiocarbon dates from within thick sedimentary units and those collected at or close to boundaries between units. The former provide a single age for processes, such as vertical sediment accretion or lateral channel migration, operating over an extended time period (Lewin et al., 2005), while the latter constrain the timing of events in the river system that produced sedimentological changes (Macklin and Lewin, 2003). In Late Pleistocene to Holocene settings, where detailed sedimentological information is more commonly preserved, radiocarbon dates on fluvial units have been classified as river activity ages, in minerogenic sediment, or river stability ages, on peat or palaeosols (Zielhofer and Faust, 2008). Sedimentary units indicative of river activity and river stability may be produced simultaneously in different depositional environments within a single reach (Zielhofer and Faust, 2008). Radiocarbon dates close to sediment unit boundaries provide maximum or minimum ages for events which produced features such as reversals in fining upwards sediment sequences or renewed fluvial sedimentation above a peat or palaeosol (Macklin et al., 2005). Radiocarbon-dated samples from a unit directly below such a sedimen- 
tological change, giving a maximum age ('change after' dates), are regarded as the most reliable indicator of the age of the event which produced the change in sedimentation rate or grain size (Macklin et al., 2010). In older deposits, where fewer units are amenable to radiocarbon dating, such precise analysis of how the dates relate to fluvial activity is less feasible. Nonetheless, the sedimentological setting should be assessed in a similar way so that the age estimate obtained can be most effectively interpreted. In addition, care should be taken to interpret the different transport pathways of the type of material to be dated.

Further to their diversity, river catchment systems are highly dynamic and material can be transported varying distances from the original source. It can also be kept in storage on hillslopes or within floodplains and released into the channel tens to thousands of years afterwards (Fig. 2). Therefore, when radiocarbon dating material from fluvial deposits, the possibility of reworking must always be borne in mind. This can be especially problematic in relation to carbon-bearing material that does not easily break down in transport (Fig. 2), for example wood, bone and some shells (either because they are calcitic, such as shell opercula, or because they are light and travel in suspension rather than bedload). Therefore, it is essential to date only the identifiable fraction of the deposit (Table 2). In addition to being identifiable, it is necessary to exercise common sense over how likely the material isolated is to have been contemporaneous with deposition (e.g. not choosing material suggesting a temperate climate if preserved within cold stage deposits).

\subsection{Calibration}

Due to natural variability in cosmic ray production and exchange between different carbon stores (i.e. ocean, terrestrial ecosystems and atmosphere) the concentration of ${ }^{14} \mathrm{C}$ in the atmosphere varies over time. For this reason, to convert radiocarbon ages to calendar ages, a detailed calibration curve has been constructed from independently dated (often annually resolved) records including tree-rings, varves, corals and speleothems. The tree-ring curve extends to 13,900 cal years BP (Reimer et al., 2013) and is the most robust part of the curve. The extension beyond this to 50,000 cal years BP is based on multiple datasets which diverge from each other in places, creating larger errors. The radiocarbon community meets regularly to review this curve and the most recent data set is IntCal13 (Reimer et al., 2013) - or SHCal13 for the Southern Hemisphere (Hogg et al., 2013), which is now included in all calibration software (e.g., CALIB, $\mathrm{OxCal}, \mathrm{BCal}$ ). The output of calibration is an interval of possible calendar ages that correspond to the ${ }^{14} \mathrm{C}$ age calculated from the measured ${ }^{14} \mathrm{C}$ concentration. Often multiple intervals correspond to the measured concentration.

\subsection{Freshwater reservoir effects and radiocarbon dating of fluvial archives}

When dating plant or shell material, the preferred habitat of the species used is crucial. If the material to be dated is from an aquatic species, the chemistry of the water body must be taken into account. The presence of 'old carbon' which is 'dead' with respect to radiocarbon can lead the ${ }^{14} \mathrm{C}$ of the water to have an apparent age. This apparent age is then transferred to the material being dated. This issue has been known for many years, with very early studies showing that Potamageton, an aquatic plant which is believed to photosynthesise within the water column, yielded an apparent age in modern hardwater lakes of 2000 years (Deevey et al., 1954). For this reason, the first choice of material to date would instead be a plant which photo-
Table 2

Sampling and laboratory techniques to improve accuracy in radiocarbon dating fluvial deposits. AMS = accelerator mass spectrometry.

\begin{tabular}{|c|c|}
\hline Issue & Sampling/laboratory solution \\
\hline \multicolumn{2}{|l|}{ 1) Dating suitable material } \\
\hline $\begin{array}{l}\text { Age difference between }{ }^{14} \mathrm{C} \\
\text { dated sediment deposit and } \\
\text { the deposit/event for which } \\
\text { an age is required }\end{array}$ & $\begin{array}{l}\text { Select samples for dating according to sedimentary } \\
\text { context and, where possible, from close to } \\
\text { boundaries between sedimentary units (c.f. 'change } \\
\text { after' dates (Macklin et al., 2010). }\end{array}$ \\
\hline $\begin{array}{l}\text { Danger of reworking of } \\
\text { fossil material either whole } \\
\text { or as organic detritus (e.g. } \\
\text { Rogerson et al., 1992) }\end{array}$ & $\begin{array}{l}\text { Date only the identifiable fraction of the deposit - } \\
\text { e.g. thoroughly cleaned specific plant macrofossils, } \\
\text { shells or bones (e.g. Turney et al., 2000). This is } \\
\text { only possible because of AMS techniques which } \\
\text { allow dating of small samples. }\end{array}$ \\
\hline \multicolumn{2}{|l|}{$\begin{array}{l}\text { Danger of field } \\
\text { contamination by modern } \\
\text { organic detritus }\end{array}$} \\
\hline \multicolumn{2}{|l|}{ 2) Freshwater reservoir effect } \\
\hline $\begin{array}{l}\text { Danger of carbon uptake } \\
\text { from carbonate rich water } \\
\text { rich in 'old' carbon }\end{array}$ & $\begin{array}{l}\text { Date only macrofossils from terrestrial species which } \\
\text { do not photosynthesise under water (e.g. Carex, } \\
\text { Scirpus). }\end{array}$ \\
\hline \multicolumn{2}{|c|}{ 3) Pretreatments to remove contaminants } \\
\hline $\begin{array}{l}\text { Danger of secondary } \\
\text { carbonate from post- } \\
\text { depositional groundwater } \\
\text { infiltration }\end{array}$ & $\begin{array}{l}\text { Dilute } \mathrm{HCl} \text { pre-treatment (first step of the mild ABA } \\
\text { below). }\end{array}$ \\
\hline $\begin{array}{l}\text { Danger of humic acid } \\
\text { infiltration from higher in } \\
\text { the profile - especially if } \\
\text { overlain by peat }\end{array}$ & $\begin{array}{l}\text { For younger samples }\left(<\sim 25{ }^{14} \mathrm{C} \text { yr BP): mild acid- }\right. \\
\text { base-acid (ABA) washes as standard pretreatment } \\
\text { For older samples, other pretreatments are } \\
\text { recommended to remove more contamination: } \\
\text { - Ultrafiltration on bone (e.g. Higham et al., 2006) } \\
\text { - ABOx-SC (acid, base, wet oxidation - stepped } \\
\text { combustion) on charcoal (Bird et al., 1999) } \\
\text { - No clear favoured protocols as yet for seeds or } \\
\text { shells }\end{array}$ \\
\hline $\begin{array}{l}\text { 4) General considerations } \\
\text { Sampling and laboratory } \\
\text { preparation. }\end{array}$ & $\begin{array}{l}\text { - Ensure laboratory space and all equipment being } \\
\text { used for preparation has never previously come } \\
\text { into contact with radioactive elements (e.g. from } \\
\text { biological researchers using }{ }^{14} \mathrm{C} \text { as a tracer element } \\
\text { - Zermano et al., 2004). } \\
\text { - Avoid organic packaging such as paper } \\
\text { - Process and store sample in deionised water only } \\
\text { - Clean working conditions, avoiding contact of } \\
\text { - } \text { - Pamples or equipment with paper where possible } \\
\text { - Visual checks for contamination } \\
\text { - Dry samples soon after identification to prevent } \\
\text { fungal growth during storage } \\
\text { - Submit as large a sample size as possible - prefer- } \\
\text { ably }>1.4 \text { mg carbon content, i.e. }>5 \text { mg dry weight } \\
\text { (Brock et al., 2010) }\end{array}$ \\
\hline
\end{tabular}

synthesises directly with the atmosphere such as Scirpus or Carex (Deevey et al., 1954).

Determining the freshwater reservoir effect in lakes (where some fluvial archives are found) is based on the assumption that the effect has remained constant and can be corrected for. In relation to rivers, this is more problematic because most studies (e.g. Deevey et al., 1954) have been carried out in lakes. A recent study (Philippsen, 2013) of water, plants and animals from rivers in northern Germany showed significant temporal variability in the scale of reservoir age in both the dissolved inorganic carbon (DIC) from river water itself (a range of 1527-3044 years) and the reservoir age in aquatic plants (a range of 350-2690 years) of particular interest is the finding that the radiocarbon values from river water are directly related to the balance 
between groundwater and precipitation inputs to the system. When precipitation was higher before samples were taken, associated radiocarbon reservoir ages of river water were younger. This means that the freshwater reservoir effect in fluvial deposits is likely to be present, but to varying degrees. The main way to avoid this issue is to date only terrestrial species of plants or molluscs (Table 2), which requires the investigator to develop some skills in fossil identification. Brauer et al. (2014, p.49) recommend for lake or speleothem sequences that where samples known to be affected by a freshwater reservoir effect have been measured, these "must be corrected prior to calibration by subtraction of the age offset estimated using the measured ${ }^{14} \mathrm{C}$ concentration of known age samples". In the fluvial setting, given the demonstrable variability in freshwater reservoir effect in relation to discharge, and the known large fluctuations in discharge regime over the time period of the radiocarbon technique, this is unlikely to be possible. The radiocarbon dating of aquatic species should therefore be avoided unless a 2000 year uncertainty is sufficient to answer the research question being posed.

\subsection{Laboratory pretreatments}

Because the concentrations of ${ }^{14} \mathrm{C}$ are so low in materials used for radiocarbon dating, the possibility of contamination with modern carbon is always present. Contamination during sample preparation can be avoided as detailed in Table 2. Removing contamination that has accumulated in situ requires laboratory pretreatment (Table 2) and becomes more crucial for samples near the limit of the radiocarbon technique between 30,000 and $50,000{ }^{14} \mathrm{C}$ years $\mathrm{BP}$, because the amount of ${ }^{14} \mathrm{C}$ present within the sample is so low that any contamination has a much larger effect (Fig. 3). This is particularly important in many discontinuous fluvial sequences where problems with dating cannot be detected in the context of a vertical sequence.

Significant progress has been made in recent years in providing more reliable radiocarbon ages on bone and charcoal from this older time period (e.g. Higham et al., 2006; Bird et al., 1999) and these pretreatments should be used for these materials. However, fluvial sequences sometimes lack these dating materials, which are best preserved in dry, alkaline conditions (the opposite of the wet, acidic conditions often present in fluvial systems for the preservation of envi-

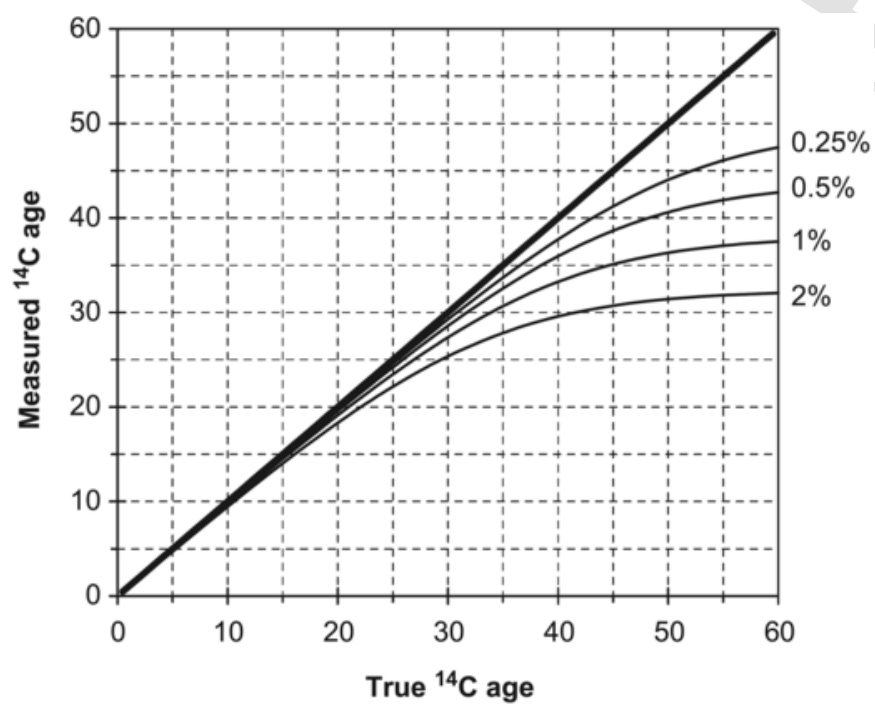

Fig. 3. The impact of modern contamination $(0.25-2 \%$ by weight $)$ on measured ${ }^{14} \mathrm{C}$ ages (thin lines) compared to the 1:1 or uncontaminated line (thickest line). After Pigati et al. (2007). ronmental material). There are as yet no 'stand-out' preferred pretreatments for the shell or seed material more commonly preserved in fluvial deposits, and advice should be sought from the radiocarbon laboratory with which you are working if the samples are likely to be near the limit of the technique.

\section{Luminescence dating of fluvial deposits}

The Optically Stimulated Luminescence (OSL) dating method is currently one of the most commonly applied to fluvial sediments because it directly dates the sand/silt grains of which such sediments are often composed. These grains enter the river system from hillslopes and then travel in suspension through the fluvial system, passing into and out of storage before final deposition (Fig. 2). This method was developed during the $1980 \mathrm{~s}$ as an alternative to Thermoluminescence (TL). It became widely used $\sim 15$ years ago, in particular due to the development of the Single Aliquot Regenerative (SAR) protocol (Murray and Wintle, 2000, 2003) which replaced previous additive approaches. The SAR protocol enables multiple age estimates to be measured from a single sample, generating more accurate final ages (Duller, 2008). Continuous improvements to precision and accuracy have occurred during past decades, giving the OSL method a key role in the dating of Quaternary fluvial archives. Many publications in special issues of the FLAG include an OSL-based geochronological approach (Table 1). Questions that have been answered by using this approach encompass, for example, the timing of phases of fluvial activity in relation to climate (e.g. Briant et al., 2004) or the dating of terrace bodies associated with archaeology (e.g. Cunha et al., 2012; this issue/2016).

Several relevant reviews related to the technical details of optical dating of fluvial deposits have been published (e.g. Wallinga, 2002; Rittenour, 2008), so the principles and basic procedures are here only briefly mentioned. Instead, we focus particularly on what researchers working on fluvial archives need to know to successfully apply this method to their samples. This includes sampling strategies, new protocols and statistical treatment of data required to derive reliable age estimates.

The OSL method is based on the estimation of the impact of radiation on the crystalline structure of minerals such as quartz and feldspar while they are shielded from light (e.g. Duller, 2004). The radiation $(\alpha, \beta, \gamma)$ comes from radionuclides which are present in the mineral and its natural environment, mainly $\mathrm{U}, \mathrm{Th}$ (and their decay products) and $\mathrm{K}$, with a small proportion from cosmic particles. This radiation leads to the trapping of electrons in crystalline lattice defects. The total amount of trapped electrons within a crystal is proportional to the total energy (dose) absorbed by the crystal, which naturally increases with time. As soon as the mineral is exposed to sunlight, especially during its transport, trapped electrons are released from the traps. This generates the emission of light (the luminescence signal) which can be measured following light stimulation (Huntley et al., 1985). The age of the sediment is then estimated by dividing the $\mathrm{D}_{\mathrm{E}}$ (equivalent dose) by the dose rate (the rate at which the sediment is exposed to natural radiation).

It should be noted that the sensitivity of mineral grains to optical stimulation is highly variable, making some depositional settings inherently more successful than others. "Quartz grains that have undergone repeated cycles of bleaching and deposition tend to become sensitized ... and so for some samples a large fraction of quartz grains will yield a measurable OSL signal ... [In contrast], samples from any environment can show poor sensitivity and highly-skewed sensitivity distributions ... [where] ... 95\% of the combined OSL signal comes from less than $5 \%$ of the grains" (Cunningham and 
Wallinga, 2012, p. 17). In addition, the commonly-used SAR protocol may not be applicable for all samples. Standard tests for the appropriateness of the SAR protocol include the use of a dose response test (i.e. can the laboratory protocol successfully remeasure a known dose?) and the recycling ratio (i.e. does the test dose successfully correct for sensitivity changes during measurement?). However, recent experimental work suggests that these may be insufficient tests (Guerin et al., 2015; Timor-Gabar et al., 2015). It is possible that this is due to an initial sensitivity change that is not corrected for by the use of the response to a test dose.

\subsection{Causes of age underestimation}

The complexities involved in generating a luminescence signal mean that in some cases it is not possible to provide a reliable age determination, either over- or under-estimating the age of the sediment. Underestimation may occur when the mineral is saturated. This means that all traps have been filled with electrons, thus preventing additional trapping. The measured signal will hence only reflect a part of the burial duration, and the obtained age must be considered as a minimum age. Saturation explains why the OSL method cannot be applied to old sediments. The age limit varies between minerals, but quartz often saturates at doses of 200-300 Gy (Table 3, Wintle and Murray, 2006). This makes it difficult to date sediments beyond $150 \mathrm{ka}$ (except when the dose rate is quite low).

Feldspars in contrast saturate at higher doses and may in theory be used to date Middle Pleistocene sediments (Table 3). However, feldspars are affected by anomalous fading. This is the spontaneous eviction of electrons from deep traps without light stimulation (Wintle, 1973) which can then lead to age underestimation. Several procedures have been developed to detect and correct for anomalous fading by estimating fading rates (Huntley and Lamothe, 2001). Another approach is the post-IR-IRSL procedure (Thomsen et al., 2008). This procedure is based on the measurement of an elevated temperature $\left(>200^{\circ} \mathrm{C}\right)$ post-IR IRSL signal immediately after the IRSL measurement (typically performed at $50{ }^{\circ} \mathrm{C}$ ). The post-IR IRSL signal is characterised by a higher stability and thus yields lower fading rates (Buylaert et al., 2009). However, the post-IR IRSL signal is harder to bleach than the IRSL signal.

\subsection{Fluvial transport and incomplete bleaching: a main source of age overestimation}

The physical principles behind OSL suggest that the method is well suited to the study of fluvial sediments, since it allows direct

Table 3

A brief overview of the OSL dating method applied to quartz and feldspar grains extracted from sediment.

\begin{tabular}{|c|c|c|c|}
\hline & $\begin{array}{l}\text { Quartz } \\
\text { (TT- } \\
\text { OSL) }\end{array}$ & Feldspar (IRSL) & $\begin{array}{l}\text { Feldspar } \\
\text { (pIR- } \\
\text { IRSL) }\end{array}$ \\
\hline $\begin{array}{l}\text { Upper dating } \\
\text { range }\end{array}$ & Present-day & & \\
\hline $\begin{array}{l}\text { Lower dating } \\
\text { range }\end{array}$ & $\begin{array}{l}\text { 200-300 Gy - i.e. c. c. } 950 \mathrm{ka} \\
150 \mathrm{ka}+ \\
\text { (depending on dose } \\
\text { rate) }\end{array}$ & $\begin{array}{l}\text { Unclear due to } \\
\text { anomalous } \\
\text { fading - c. } \\
300 \mathrm{ka} \text { ? }\end{array}$ & c. $950 \mathrm{ka}$ \\
\hline $\begin{array}{l}\text { Main strength } \\
\text { of the } \\
\text { application }\end{array}$ & \multicolumn{3}{|c|}{$\begin{array}{l}\text { Can date fluvial sediments directly. } \\
\text { Can date beyond the C-14 dating time range. } \\
\text { TT-OSL and pIR-IRSL can extend back to c. } 1 \mathrm{Ma}\end{array}$} \\
\hline $\begin{array}{l}\text { Standard } \\
\text { precision }\end{array}$ & \multicolumn{3}{|c|}{ Standard errors are usually $\sim 10 \%(5-15 \%)$} \\
\hline
\end{tabular}

dating of the last transport-and-sedimentation process (Table 3). However, in addition to the mineral-related issues described above, a key issue related to the dating of fluvial sediments is the potential occurrence of incomplete bleaching. This phenomenon occurs when grains have not been exposed to sufficient daylight during transport. In this case, a part of the measured OSL signal is formed by electrons that remained trapped despite the fluvial transport (inherited component; Murray and Olley, 2002). This leads to an overestimation of the age, which is significant in the case of young sediments (less than $2 \mathrm{ka}$; Jain et al., 2004), but may also affect older sediments. For this reason, the detection and avoidance of incomplete bleaching is fundamental to obtain reliable burial ages to infer the timing of deposition.

In the case of fluvial sediments, these should be selected for sampling to maximise bleaching in the depositional setting. The degree of bleaching of the individual grains depends on two main parameters (Stokes et al., 2001): transport length, and the transport conditions. Sufficient transport is necessary to ensure complete bleaching of the signal. Studies focusing on transport length showed that the inherited signal was significantly reduced after a transport of several tens or hundreds of km (Murray and Olley, 2002). The second parameter refers to the way the grains are transported and includes, amongst others, the water turbidity and the channel depth. Grains that have been transported in a deep water column (leading to strong attenuation of the solar spectrum) and/or in turbid water may therefore be incompletely bleached (e.g. Ditlefsen, 1992). Settings in which samples are more or less likely to be completely bleached are represented in Fig. 2. However, the expertise of the researcher must be employed at the site to truly maximise the likelihood of sampling completely bleached material, since the presence of turbid water or a deep water column will usually leave a sedimentary signature.

\subsection{The importance of the sampling strategy}

Following from this, the sampling strategy should aim to collect the potentially best bleached grains, keeping in mind that the OSL method is mainly applied to sand- $(100-250 \mu \mathrm{m})$ or silt- $(4-11 \mu \mathrm{m})$ sized grains. This makes it necessary to perform fine sedimentological investigations to interpret the depositional locations (i.e. channel/ palaeochannels, point bar, crevasse splay, floodplain deposits). Most sediments analysed to date have been collected in channels or point bars (Figs. 2 and 4), as these are more clearly associated with significant transport of the grains. OSL dating of floodplain deposits is less common, but possible especially in the case of sandy facies (Keen-Zebert et al., 2013). Considering the sedimentation process is also very important, as the exposure to sunlight will be different in a flood dominated river (typical of Mediterranean or semi-arid areas) or a less ephemeral river. In the latter, presence of a more regular water flow will allow grains to be more completely bleached, while in the former case mass transport associated with floods may prevent complete zeroing (Bartz et al., 2015).

In common with all depositional locations, the sampling should ideally be performed in thick $(>30 \mathrm{~cm}$ both above and below the sample) homogeneous layers, to ensure that the dose rate estimation is as simple as possible (Fig. 4a). This is particularly important if the field scientist does not have access to a field gamma spectrometer which can capture the dose rate from this full radius of gamma radiation (Fig. 4b). In the common case of a thinner bed surrounded by inhomogenous sediments, detailed attention should be paid to the 'micro-stratigraphy' and small samples for laboratory dose rate measurement taken from all sediment types within a $30 \mathrm{~cm}$ radius of the sample. These can have significantly different dose rates (clays are often higher, gravels lower) and this can be adjusted for using the 

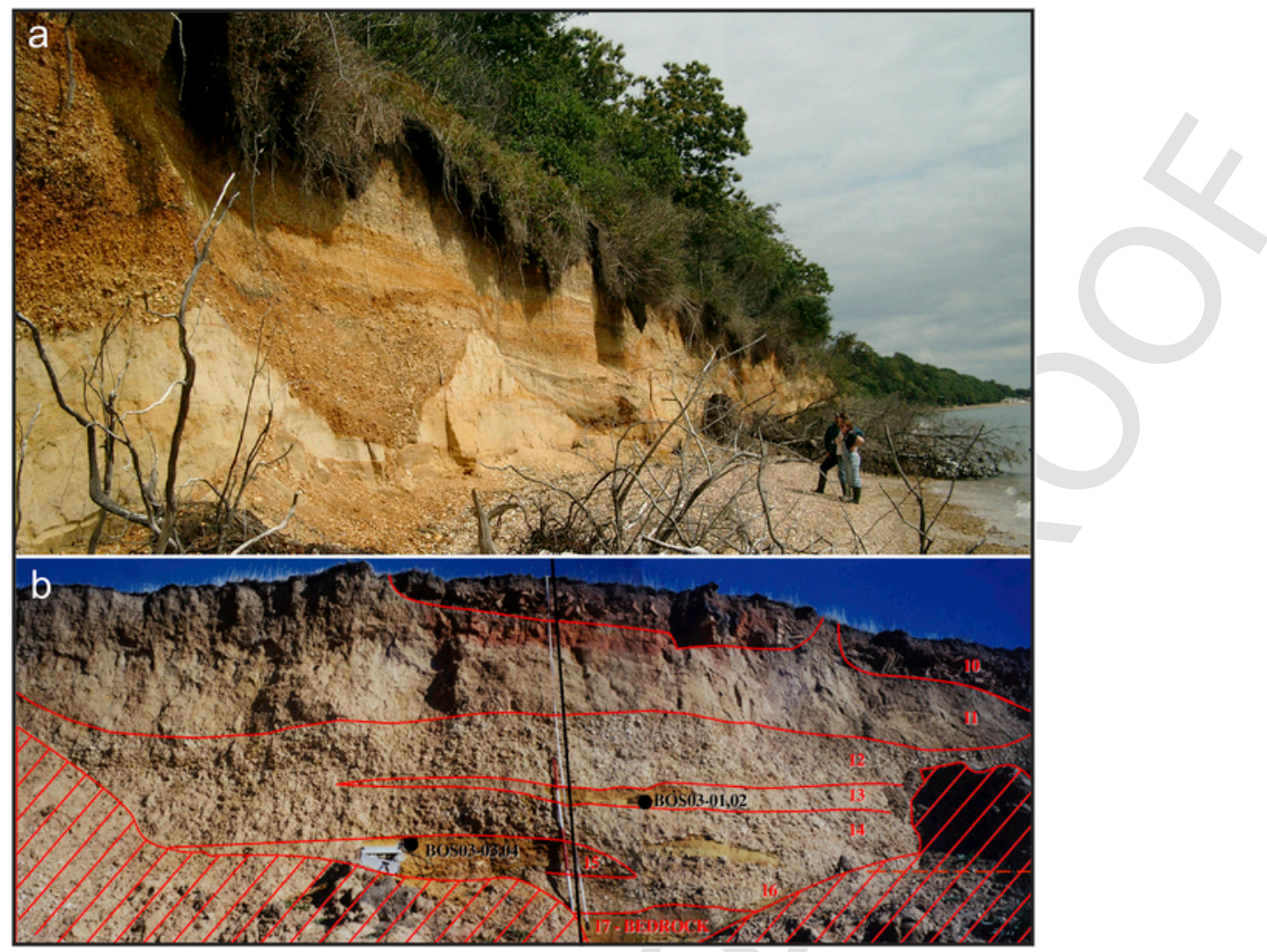

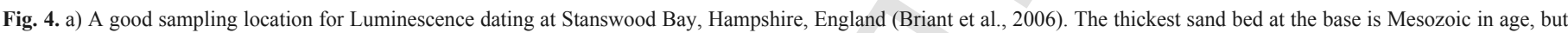

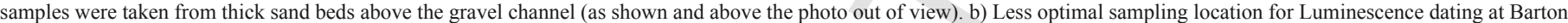
on Sea, Hampshire, England (Briant et al., 2006). Field gamma spectrometry was undertaken to mitigate the complex dose rate effect of the thinner sand lenses.

methods published by Aitken (1985) if such samples are taken. It is worth being aware, however, that the greater complexity of dose rates and lower likelihood of complete bleaching may make the results from such samples hard to interpret.

The choice of the mineral to be studied as a dosimeter is also crucial, if a choice is possible. Both theoretical work and comparative analyses by Wallinga et al. (2001) showed for Upper Pleistocene to Holocene sediments that quartz was a preferred dosimeter. The quartz grains are more rapidly bleached than feldspars (a few seconds vs a few tens of seconds, Huntley et al., 1985), and not affected by anomalous fading. For older deposits, trade offs must be made, and feldspars may be selected to allow dating of older deposits, with anomalous fading effects taken into account and corrected for as well as possible.

This sedimentological approach is fundamental in selecting the grains with the best properties for dating. However, it may in some cases not be sufficient to avoid heterogeneous bleaching. There are measurement protocols that seek to avoid partial bleaching by measuring or reporting only the well-bleached component within a sample (e.g. 'early background subtraction', Cunningham and Wallinga, 2010, or combined IR and OSL stimulation, Jain et al., 2005). However, none of these methods have become mainstream approaches as yet. It is also worth noting that field investigations and sampling may benefit from the use of recently developed portable readers (Sanderson and Murphy, 2010). These make it possible to broadly estimate luminescence intensities and, when combined with in situ gamma spectrometry, the depositional age. Whilst the precision is too low for this to replace laboratory measurements, it may be a useful tool in the case of complex depositional patterns, to detect potentially problematic samples and guide sampling strategies (Stone et al., 2015). It has yet to be tested on fluvial sediments, or at the lower luminescence intensities typical of temperate-zone samples.

\subsection{Detection of incomplete bleaching during OSL measurements and statistical treatments to address this issue}

Incomplete bleaching can be detected while performing luminescence measurements in the laboratory. Large-scale assessments can be made firstly by measuring both quartz and feldspars for a given sample. As the dosimeters have different bleaching rates, obtaining comparable ages provides evidence for complete zeroing of the sediments prior to burial (Colarossi et al., 2015). The testing of modern analogues (recent sediments transported under conditions similar to those under study) may also be useful (e.g. Geach et al., 2015), provided such sediments are available.

It is possible to statistically separate different parts of the luminescence signal to isolate the 'fast' component, which is most easily bleached (e.g. Singareya and Bailey, 2004). The most common way of detecting incomplete bleaching in the laboratory, however, is through investigation of the distribution of multiple age estimates from a sample. The SAR protocol is based on the measurement of multiple equivalent doses (from aliquots or single grains) for a given sample. The number of aliquots used varies, but Rodnight (2008) proposed 50 aliquots as a minimum based on analysis of a poorly bleached fluvial sample. In some case higher values are required or lower may be sufficient (Galbraith and Roberts, 2012). It is important that these measurements are performed on small aliquots or single grains to avoid averaging of the signal across the aliquot.

The initial assumption is that a fully bleached sample will yield consistent $\mathrm{D}_{\mathrm{E}}$ values (excluding analytical uncertainty). Therefore, 
the presence of scattering in the $\mathrm{D}_{\mathrm{E}}$ distribution is taken as an indication that some aliquots have been incompletely bleached. Whilst this is commonly represented as a histogram or probability density function, recently many workers have started to use radial plots which allow the inclusion of information on the precision of each $\mathrm{D}_{\mathrm{E}}$ (e.g. Galbraith, 2010; Fig. 5). Use of appropriate statistical methods for plotting and choosing an average $D_{E}$ has been made simpler for the non-specialist by the recent development of the $\mathrm{R}$ package for Luminescence dating (Kreutzer et al., 2012). The overdispersion parameter, defined as the remaining dispersion after having considered the uncertainty sources associated with the measurement, is seen as an indicator of the likely presence of partial bleaching (Colarossi et al., 2015). However, it is difficult to propose a single threshold value for this since other parameters also influence overdispersion (Thomsen et al., 2012).

Following investigation of the shape of the distribution, the $\mathrm{D}_{\mathrm{E}}$ value used for the final age determination is derived from several 'age models' (Lauer et al., 2010), all available in the R package for Luminescence (Fuchs et al., 2015). The most commonly used are the Common Age and Central Age Models (combining the calculation of overdispersion with that of the weighted mean), which are appropriate when the overdispersion is zero or low, respectively (no significant evidence for partial bleaching). The Minimum Age Model (Galbraith and Laslett, 1993) is used for samples with higher overdispersion values to identify the most well bleached aliquots and bases the age estimate on these. Finally the Finite Mixture Model (Galbraith and Green, 1990) can be applied to single grains only (Galbraith and Roberts, 2012) and allows the detection of discrete populations. In all these cases, however, the choice of the age model to be used is often subjective, since there is no set threshold value of overdispersion to use for choosing between different age models. Bayesian methods have been used for a number of years by the radiocarbon community and are useful in robustly identifying outliers and thereby increasing precision. Such approaches have recently been tested on OSL samples (e.g. Cunningham and Wallinga, 2012; Guerin et al., 2015). Cunningham and Wallinga applied a combination of bootstrap likelihoods and Bayesian methods to young $(<1 \mathrm{ka})$, partially bleached samples from a vertical floodplain sequence in the Netherlands. The bootstrap likelihoods were used to provide a probability density function for each sample that was statistically appropriate for Bayesian analysis. This approach was useful in this setting, but can only be applied where there is sufficient sample density for the stratigraphical relationships to be known and the age distributions to overlap.

The need for such complex statistical treatment of the results may be considered a drawback of the luminescence dating method, since the obtained age is dependent on the model used. However, when explained fully and justified in relation to luminescence characteristics, this approach leads to greater confidence in the robustness of the results. The selection of the "best" model then derives from a rigorous analysis of all the available data, including not only the measurement values, but also the field and sedimentological evidence (which can be useful for example to assess the bleaching potential of the sediments). Furthermore, recent developments in the use of Bayesian statistics hold out a hope that a single approach to determining equivalent dose may soon be possible where stratigraphical relationships are clear.

\subsection{A key issue for the future: extending OSL dating to the Middle Pleistocene}

Whilst fluvial sediments of Middle Pleistocene age have been dated, especially using IRSL on feldspars, extending the age range to older sediments remains a major issue (Table 3 ). This is also of significant importance for the FLAG community as it will allow a longer-term reconstruction of valley evolution during the Pleistocene. Several protocols have been developed to date older sediments, including the pIR-IRSL method discussed above.

For quartz, a new approach is the measurement of the Thermally Transferred OSL signals (TT-OSL; Wang et al., 2006). These signals are observed after stimulation and heating of the quartz grains and result from a complex charge transfer associated with the heating. As they saturate at much higher doses than the OSL signal, they might be used for dating older sediments (Table 3). Arnold et al. (2015) compared single-grain TT-OSL and pIR-IRSL at the Atapuerca hominin site where independent age control is available. When they used measurement temperatures of $225^{\circ} \mathrm{C}$, they found good agreement for both methods from 240 to $930 \mathrm{ka}$, though pIR-IRSL measurements at $290{ }^{\circ} \mathrm{C}$ gave overestimates. Arnold et al. (2015) argue therefore that multiple methods should be used in extended range dating, since each is more reliable in different settings. This view
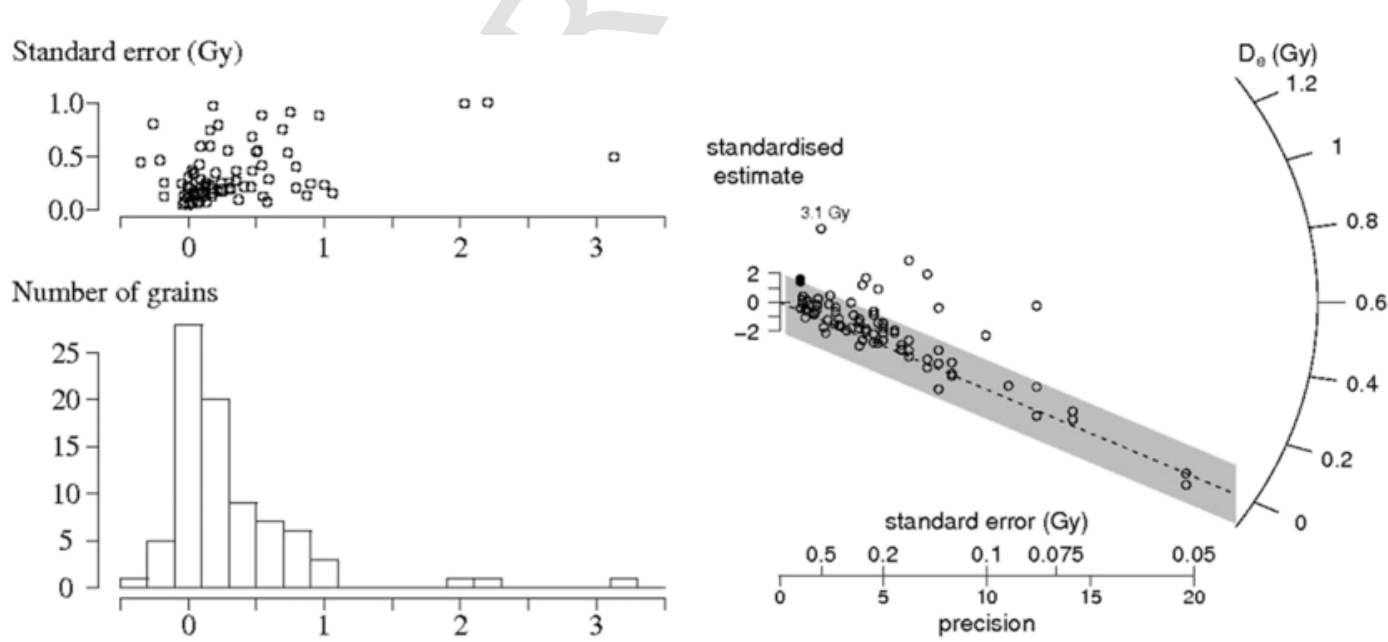

Equivalent dose (Gy)

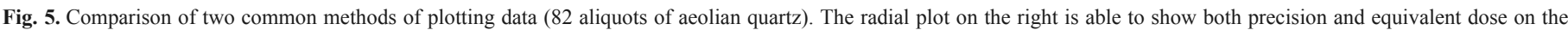
same plot. This is not possible with the histogram on the left, nor with commonly used probability density plots. Figures 1 and 2 of Galbraith (2010). 
seems also relevant for the new developments in Luminescence dating, such as the Infra-Red Radio-Fluorescence (IR-RF) or the Violet Simulated Luminescence, for which further investigations are required prior to validate their suitability for dating ancient fluvial archives. It is worth noting that these approaches do not address uncertainties in estimating dose rates, which remain significant also at older ages.

\section{Electron Spin Resonance (ESR) dating in fluvial environments}

ESR is a radiation exposure (or palaeodosimetric) dating method based on the evaluation of the natural radiation dose absorbed by materials over geological times. The first application of ESR as a geochronologic tool was published by Ikeya (1975) on stalagmites from Japanese caves. Since then, the method has been used on a wide range of materials including phosphates, carbonates, and silicates (see review in Ikeya, 1993). The most popular applications in fluvial context are undoubtedly on fossil teeth and optically bleached quartz grains extracted from sediment, either for targeted dating of a given site/section (e.g. Falguères et al., 2006; Santonja et al., 2014) or for the establishment of a comprehensive chronological framework for terrace staircases (e.g. Voinchet et al., 2004; Antoine et al., 2007; Cordier et al., 2012). As with Luminescence dating, ESR dating is based on the quantification of charge trapped in the crystalline lattice of a material under the effect of natural radioactivity. These trapped charges give rise to an ESR signal whose intensity is proportional to the radiation dose absorbed by the sample over time. The ESR age equation is similar to that used in luminescence dating and the standard analytical procedure consists in determining the two main parameters: the equivalent dose $\left(D_{E}\right)$ and the dose rate. $D_{E}$ is obtained using ESR spectroscopy, by artificially aging the samples at increasing doses in order to describe the behaviour of the studied signal. The dose rate is usually assessed by a combination of in situ and laboratory measurement using a wide range of different analytical techniques and corrected for the density of the material, its geometry and water content (see Grün, 1989; Duval, 2016).

\subsection{ESR dating of fossil teeth: on the importance of modelling uranium incorporation into dental tissues}

ESR dating of fossil teeth has been first proposed in the mid-1980s as an alternative to fossil bones (see an overview by Duval, 2015 and references therein). The main difficulty of this application lies in the complexity of the system that has to be considered for the dose rate evaluation. A tooth is made from different dental tissues (dentine, enamel and, sometimes, cement). Al have different characteristics in terms of composition and thickness contribute to the irradiation of the enamel layer. Additionally, dental tissues are known to behave as open systems for U-series elements. In other words, teeth frequently experience delayed U-uptake or U-leaching processes. As a consequence, it is crucial to model the kinetics of the incorporation of $U$ into each dental tissue in order to obtain an accurate estimation of the dose rate. The most common, and reliable, method is using the U-series data collected for each dental tissue in combination with the ESR dose evaluation (i.e., the so-called combined U-series/ESR dating approach; see Grün et al., 1988 and Grün, 2009). Further detail is found in a recent review by Duval (2015) and Table 4.
Table 4

A brief overview of the ESR dating method applied to fossil teeth and optically bleached quartz grains extracted from sediment. Further details regarding the dating time range of each application may be found in Duval (2016) and references therein.

\begin{tabular}{|c|c|c|}
\hline & Fossil tooth enamel & $\begin{array}{l}\text { Optically bleached quartz } \\
\text { grains extracted from } \\
\text { sediment }\end{array}$ \\
\hline Dated event & $\begin{array}{l}\text { Burial of the fossil tooth (usually } \\
\text { assumed to happen shortly after the } \\
\text { death of the animal). }\end{array}$ & $\begin{array}{l}\text { Last exposure of the } \\
\text { sediment to sunlight }\end{array}$ \\
\hline $\begin{array}{l}\text { Main specificity } \\
\text { of the } \\
\text { application }\end{array}$ & $\begin{array}{l}\text { Dental tissues are open-systems for } \\
\text { U: U-uptake needs to be modelled } \\
\text { (combined U-series/ESR dating } \\
\text { approach). }\end{array}$ & $\begin{array}{l}\text { Light-sensitive ESR } \\
\text { signals (same basic } \\
\text { principles as OSL } \\
\text { dating). } \\
\text { Presence of a residual } \\
\text { (non-bleachable) ESR } \\
\text { intensity for the Al } \\
\text { centre. }\end{array}$ \\
\hline $\begin{array}{l}\text { Upper dating } \\
\text { range }\end{array}$ & Present-day & $\sim 10 \mathrm{ka}$ \\
\hline $\begin{array}{l}\text { Lower dating } \\
\text { range }\end{array}$ & Early Pleistocene & Miocene (Al-centre) \\
\hline $\begin{array}{l}\text { Optimum dating } \\
\text { range }\end{array}$ & $40-800 \mathrm{ka}$ & $200 \mathrm{ka}-2 \mathrm{Ma}$ \\
\hline $\begin{array}{l}\text { Main strength of } \\
\text { the application }\end{array}$ & $\begin{array}{l}\text { Direct dating of hominin and animal } \\
\text { fossil remains beyond the C-14 and } \\
\text { U-series dating time range. }\end{array}$ & $\begin{array}{l}\text { May date beyond the OSL } \\
\text { dating time range. }\end{array}$ \\
\hline $\begin{array}{l}\text { Standard } \\
\text { precision }\end{array}$ & $\begin{array}{l}\text { Standard errors are usually } \sim 10 \% \\
(5-15 \%)\end{array}$ & $\begin{array}{l}\text { Standard errors are } \\
\text { usually } \sim 10 \%(5-15 \%)\end{array}$ \\
\hline
\end{tabular}

4.2. ESR dating of sedimentary quartz grains: the choice of signal to measure

Similar to OSL, ESR dating of sedimentary quartz is based on the study of light-sensitive signals whose intensity is reset (bleached) under sunlight exposure during sediment transportation. Once the sediment is buried, and thus sheltered from sunlight, paramagnetic centres are created and the ESR signal intensity increases as a result of the interaction of natural radioactivity with the quartz sample. Quartz has several paramagnetic centres associated with crystal defects (for a detailed review, see Ikeya, 1993; Preusser et al., 2009), but the most widely used since the first dating application by Yokoyama et al. (1985) are undoubtedly the Titanium (Ti) and the Aluminum (Al) centres. Because $\mathrm{Al}$ is the major trace element found in quartz (Preusser et al., 2009), the ESR signal associated with the Al centre can be observed in any sample. It also usually presents high intensities (Fig. $6 a)$ and signal-to-noise ratio values, ensuring high precision measurements (Duval, 2012). However, the Al signal shows relatively slow bleaching kinetics (the signal requires several hundred hours of UV laboratory irradiation to reach a minimum value, see Fig. 6b), and it cannot be fully reset under sunlight exposure as there is a residual ESR intensity that cannot be bleached (Fig. 6b; Toyoda et al., 2000). This residual level should be assessed (usually via bleaching experiments using sunlight simulators) in order to avoid dose overestimations. In contrast, the $\mathrm{Ti}$ centres ( $\mathrm{Ti}-\mathrm{Li}$ and $\mathrm{Ti}-\mathrm{H}$ mostly in quartz samples) show much faster bleaching kinetics and no residual (i.e. unbleachable) ESR intensity. However, measurements are significantly longer and less precise than those of the Al centre given the very low ESR intensities that are usually measured (Fig. 6a, Duval and Guilarte, 201z). Further detail about ESR dating of optically bleached quartz grains may be found in the recent reviews by Toyoda (2015) and Tissoux (2015), while basic information is also given in 4 . 

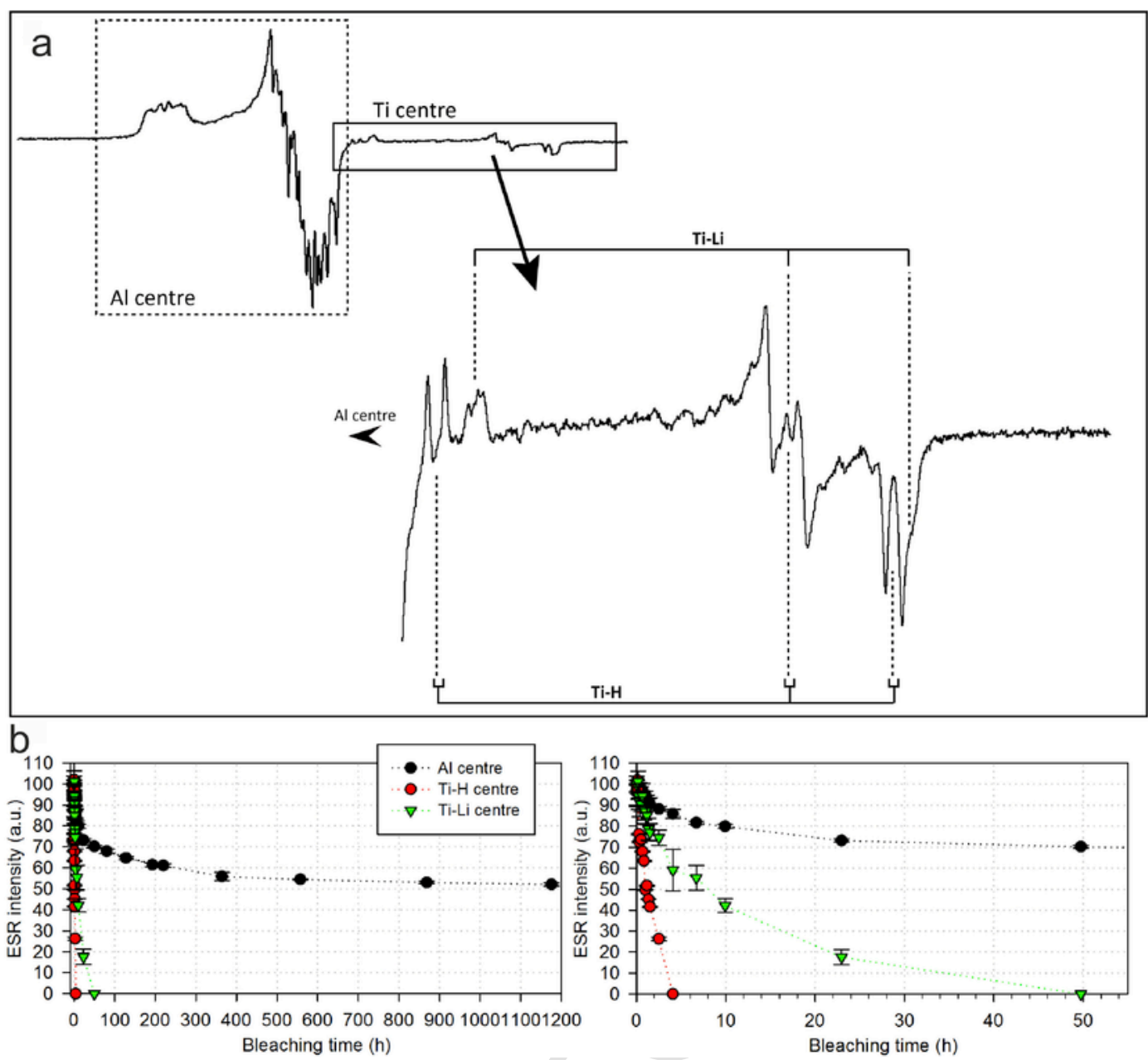

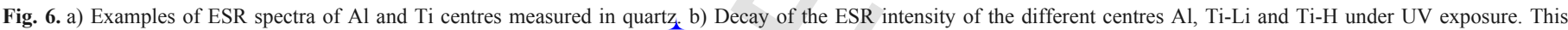
laboratory bleaching experiment was performed with a SOL2 sunlight simulator (Dr Hönle) on a quartz sample from the Morée-Villeprovert locality, France.

\subsection{Fluvial environment and ESR dating: main specificities}

Depending on the material dated, there may be different impacts from the fluvial environment on the ESR dating results. Unlike in quartz, the ESR signal measured in tooth enamel is not light sensitive and thus cannot be reset during transportation. However, transport and depositional conditions can indirectly impact the ESR results, in particular regarding the preservation state of the sample, as they may fragment and weaken dental tissues, thus favouring post-depositional processes and in particular U-uptake or leaching. Additionally, a review by Grün (2009) showed that the U-uptake kinetics into dental tissue is significantly different depending on the sedimentary environment: teeth found in cave sites most frequently document earlier U-uptake compared with those found in open air sites, which also show more frequent occurrences of U-leaching. This is most likely due to differences in the sedimentological context. Cave sites, as closed environments, usually offer more stable geochemical conditions over time. In contrast, open air sites are frequently found as the result of erosion processes that may induce modifications of the hydrological environment and cause recent mobilisation of radioelements impacting the original isotopic signature of the teeth.

Fluvial transport has a direct impact on the ESR signals measured in quartz as it is known to induce resetting by either exposure to nat- ural sunlight (Toyoda et al., 2000) or mechanical effects (Liu and Grün, 2011). Similarly to OSL, the degree of bleaching of the ESR signals depends on the length and conditions of transport (see Section 3.2.). In a recent study, Voinchet et al. (2015) studied the impact of a series of parameters such as the grain size, transport mode and water turbidity to evaluate the most suitable conditions for optimum bleaching. Based on their results, higher bleaching levels achieved for $100-200 \mu \mathrm{m}$ grains in comparison with other fractions and for fluvial transport under clear water conditions (see overview in Fig. 2).

\subsection{Sampling precautions}

When dating sedimentary quartz, sampling precautions are very similar to those for Luminescence dating (Section 3.3), i.e. the choice of a suitable sedimentary setting and suitably thick beds for simplicity of dose-rate estimation (Fig. 4). Although ESR signals bleach much slower than OSL ones, it is nevertheless important to minimise the exposure of the raw sediment to the sunlight during sampling, as in luminescence dating. According to the results shown by Voinchet et al. (2015), sediment showing a non-negligible fraction of medium sands (mostly 100-200 $\mu \mathrm{m}$ ) and transported and deposited in a clear-water fluvial environment should be targeted for sampling, as they potentially offer the most suitable bleaching conditions. In ad- 
dition, in situ measurements of natural radioactivity should be undertaken (especially if the immediate surrounding sedimentary environment is not homogeneous, see Fig. 4b), in order to obtain an accurate estimation of the gamma dose rate. Additional small bags of sediment are also usually collected at the ESR sampling spot for future laboratory analysis, e.g. for water content evaluation and analysis of radioelement concentration. When dating teeth, samples have usually already been collected during the archaeo-palaeontological excavation and are thus chosen from collections. It is important to make sure that exact original (geographical and stratigraphical) location of the selected tooth is well-known and the corresponding layer/outcrop/site is still accessible to enable complementary fieldwork sampling and dose rate measurements. Ideally, in the case of fossil teeth it is recommended to ask the archaeologists and/or palaeontologists to collect the sediment attached to the tooth during the excavation. This is essential for a correct evaluation of the beta, and sometimes gamma, dose rate component(s). The apparent preservation state of the tooth matters as well, as previous studies have shown a strong correlation between macroscopic cracks in dental tissues and preferential migration of U-series elements (Duval et al., 2011).

\subsection{Current challenges in ESR dating}

\subsubsection{ESR dating of fossil tooth enamel: improving resolution and removing unstable components of the ESR signal}

In comparison with quartz, ESR dose reconstruction of fossil tooth enamel is more straightforward. The composition of the ESR signal and its dose response has been extensively studied in recent decades. The modern development of ESR analyses of enamel fragments now enables the differentiation of the relative contribution of non-oriented $\mathrm{CO}_{2}{ }^{-}$radicals (NOCORs) vs. the oriented ones (CORs) (e.g. Grün et al., 2008). Additionally, Joannes-Boyau and Grün (2011) showed that laboratory gamma irradiation produces additional unstable NOCORs in comparison with natural irradiation, which may lead to dose underestimation $(\sim 30 \%)$ if this contribution is not removed. The authors acknowledge, however, that this value should not be considered as universal and extrapolated to any samples, as it may depend on many parameters (e.g., age, type, species). In contrast, more recent investigations indicate that this preferential creation of an unstable component may not be systematic, being rather sample dependant (Duval and Grün, unpublished data). Consequently, from these results it seems that each sample should be independently assessed. However, as an additional complication, it should be mentioned here that most of the dating studies are performed on enamel powder. One of the major current challenges would thus be to develop an analytical procedure that enables an easy identification of these unstable NOCORs using enamel powder. In that regard, using the microwave saturation characteristics of the different groups of $\mathrm{CO}_{2}^{-}$(Scherbina and Brik, 2000) may be an avenue worth exploring in the future.

High resolution LA-ICP-MS U-series analyses has recently demonstrated the spatial heterogeneity of the distribution of U-series elements in dental tissues (Duval et al., 2011). This analytical tool has rapidly become essential for studying U-mobility and may be particularly useful to identify domains in the teeth that are suitable for ESR dating. However, the use of this technique raises new issues. There is a difference in resolution when comparing ESR and the ICP-MS methods. Currently, in situ laser ablation ICP-MS U-series analysis can be performed with a resolution of a few tens of $\mu \mathrm{m}$. In contrast, the spatial variation of the ESR signal intensity in tooth enamel has rarely been studied, and ESR bulk analyses are usually performed on several hundreds of $\mathrm{mg}$ of enamel powder. This dif- ference in resolution may become a non-negligible source of uncertainty in ESR dating, especially for old samples for which the dose rate associated with dental tissues is the major factor in the total dose rate calculation. Future challenges will thus consist of developing new approaches to reduce the amount of sample required for ESR analyses and obtain spatially resolved data. This now posible through the use of high sensitivity X-band resonators and with the development of a specific analytical procedure for quantitative measurements in Q-band spectroscopy based on only a few $\mathrm{mg}$ of enamel (Guilarte et al., 2016). Additionally, although it is for the moment extremely complicated to integrate spatially-resolved ESR and U-series data for age calculations, the recent development of DosiVox (software for dosimetry simulations) opens new possibilities for modelling dose rates from complex geometries and heterogeneous spatial distributions of radioelements (Martin et al., 2015).

\subsubsection{Avoiding and minimizing the effect of scatter and incomplete bleaching in ESR dating of sedimentary quartz}

One of the main difficulties in ESR dating of quartz is to achieve repeatable measurements ensuring reproducible $D_{E}$ results. This reproducibility is lower than that obtained with tooth enamel, not only because measurements close to liquid $\mathrm{N}_{2}$ temperature require a very stable experimental setup, but also because of the heterogeneity of the quartz samples and the strong angular dependence of the signal within the cavity. Extensive work has been performed recently to optimise the conditions of measurements for both the $\mathrm{Al}$ and $\mathrm{Ti}$ centres (e.g. Puval and Guilarte, 2012, 2015: Duval, 2012).

In parallel to this work, another major challenge is in reducing the uncertainty on the final $\mathrm{D}_{\mathrm{E}}$ value. As noted by Toyoda (2015), some approaches developed in OSL dating are definitely worth exploring in ESR dating. Perhaps the most obvious is the use of the regenerative dose protocol instead of the additive dose protocol that is routinely used in ESR. This protocol would not only provide more precise $\mathrm{D}_{\mathrm{E}}$ results but also significantly shorten the analytical time (i.e. fewer aliquots to be measured and lower irradiation dose values). However, several previous attempts employing optical bleaching resetting have shown somewhat contrasting results regarding the presence of sensitivity changes (Tissoux et al., 2007; Beerten and Stesmans, 2006). Other approaches are less obviously fruitful. For example, although single grain dating using Q-band ESR spectroscopy has been tested to identify partial bleaching among a grain population, it is currently too complicated to be applied routinely (Beerten and Stesmans, 2006).

The main challenge, however, is in minimizing the uncertainty regarding possible incomplete bleaching of the signal during sediment transportation. Most dating studies use the Al centre even though laboratory bleaching experiments indicate that several hundreds of hours of exposure to UV are required for the ESR signal to decay to a plateau (e.g. Toyoda et al., 2000; see also Fig. 6b). These values would correspond to several tens of days of sunlight, which understandably leads many authors to question the possibility of the Al centre actually reaching its residual ESR intensity during transportation. However, Voinchet et al. (2007) demonstrated that the signal was fully reset (to its residual level) after only $1 \mathrm{~km}$ of transportation in the Creuse river, France. Additionally, at the Vallparadís site (Spain), Al-ESR ages were found to be in good agreement with the US-ESR ages on fossil teeth and data from magneto- and bio-stratigraphy (Duval et al., 2015). These two examples demonstrate that any definitive conclusion derived from laboratory bleaching experiments should be considered with caution. It is possible that other processes, not yet understood, are involved in the bleaching of the signal in natural conditions. 
As a consequence of the uncertainty that may arise from the bleaching of the Al centre, ESR age results based on this centre should be considered as maximum possible ages: the true age of the deposits being either similar or younger. To constrain this uncertainty, a few strategies are available. The use of modern analogue samples collected from nearby river banks may provide some useful information regarding resetting of the signal. This approach is, however, based on the assumption that transportation and bleaching conditions are similar to those in the past, which is not always plausible. Another approach is to use independent age control to verify the age results (see the example of Vallparadís, Duval et al., 2015). However, the best option is undoubtedly the Multiple Centres (MC) approach proposed by Toyoda et al. (2000). The authors proposed the systematic measurement of both the Ti-Li and Al centres in quartz samples in order to check whether they would provide consistent results (Table 5). If the $\mathrm{Al}$ centre yields an age estimate older than that of the Ti centre, this is interpreted as incomplete bleaching of the $\mathrm{Al}$ signal. In this case, the Ti-Li age should be considered a closer estimate to the burial age of the deposits. Although ESR measurements following the MC approach are highly time consuming, it has provided promising results (see Rink et al., 2007; Duval et al., 2015). The use of this MC may soon become a standard requirement in ESR dating of optically bleached quartz grains.

Lastly, another Ti centre, Ti-H, presents great potential worth investigating for dating purposes. It is known to bleach much faster and to be more radiosensitive than the Ti-Li (see Fig. 6b; Duval and Guilarte, 201z), which would make it a good candidate for dating deposits younger than $200 \mathrm{ka}$. It is, however, unclear for the moment whether it provides reliable dose estimations. Indeed, the weakness of the signal intensity makes it very complicated to measure in all samples, resulting in low measurement precision (Table 5; Duval and Guilarte, 2012).

\section{5. ${ }^{230} \mathrm{Th} / \mathrm{U}$-dating of fluvial deposits}

The ${ }^{230} \mathrm{Th} / \mathrm{U}$-dating method is based on the radioactive decay in the natural decay chain of ${ }^{238} \mathrm{U}$ and was developed in the $1960 \mathrm{~s}$ (Broecker, 1963; Kaufman and Broecker, 1965). Since then, the precision and accuracy of the method has progressively increased, primarily due to major technical advances. Whereas alpha spectrometry was widely used until the 1990s (Goldstein and Stirling, 2003), the use of thermal ionisation mass spectrometry (TIMS) (Edwards et al., 1987) represented a major advance at the end of the 1980s. This re-

Table 5

Summary of the main features usually observed for the three paramagnetic centres $\mathrm{Al}$, Ti-Li and Ti-H. Relative characterisation is provided: $(+++)=$ high, $(++)=$ medium, $(+)=$ low. Further details and additional references may be found in the text.

\begin{tabular}{|c|c|c|c|}
\hline & Al centre & Ti-Li centre & Ti-H centre \\
\hline $\begin{array}{l}\text { Signal-to-noise ratio } \\
(\mathrm{S} / \mathrm{N})\end{array}$ & +++ & ++ & + \\
\hline $\begin{array}{l}\text { Precision of the } \\
\text { measurements }\end{array}$ & +++ & ++ & + \\
\hline Dose response curve & $\begin{array}{l}\text { No apparent } \\
\text { saturation at } \\
\text { high doses } \\
\text { (>60 kGy) }\end{array}$ & $\begin{array}{l}\text { Non-monotonic } \\
\text { behaviour } \\
\text { (maximum } \\
\text { intensity } \\
\sim 6-10 \mathrm{kGy} \text { ) }\end{array}$ & $\begin{array}{l}\text { Non-monotonic } \\
\text { behaviour } \\
\text { (maximum } \\
\text { intensity } \\
\sim 3-8 \mathrm{kGy} \text { ) }\end{array}$ \\
\hline $\begin{array}{l}\text { Bleaching kinetics } \\
\text { (speed) }\end{array}$ & + & ++ & +++ \\
\hline $\begin{array}{l}\text { Residual ESR } \\
\text { intensity } \\
\text { (unbleachable } \\
\text { component) }\end{array}$ & Yes & No & No \\
\hline
\end{tabular}

duced the time required for an analysis from a week to several hours, decreased sample size from $10-100 \mathrm{~g}$ to $0.1-1 \mathrm{~g}$ and, most importantly, improved precision from percent to permil levels and extending the dating range from 350 to $600 \mathrm{ka}$ (Goldstein and Stirling, 2003). In the last two decades, the application of multi-collector inductively coupled plasma mass spectrometry (MC-ICPMS) has led to further substantial improvements (Goldstein and Stirling, 2003; Scholz and Hoffmann, 2008). The considerably higher ionisation and transfer efficiency for $\mathrm{U}$ and Th isotopes of the MC-ICPMS technique leads to higher count rates, in turn resulting in more precise and accurate ${ }^{230} \mathrm{Th} /$ U-ages. Furthermore, measurement times ( 10-20 min) and sample sizes are again substantially lower than for TIMS. In addition to the technical advances, the half-lives of both ${ }^{230} \mathrm{Th}$ and ${ }^{234} \mathrm{U}$ have been re-determined (Cheng et al., 2000, 2013), also leading to more precise ${ }^{230} \mathrm{Th} / \mathrm{U}$-ages. During the last decade, procedures for laser-ablation (LA) MC-ICPMS ${ }^{230} \mathrm{Th} / \mathrm{U}$-dating of carbonates have been developed (e.g. Eggins et al., 2005; Mertz-Kraus et al., 2010). This technique has very large potential since it offers in situ dating at extremely high spatial resolution (in the range of 10-100 $\mu \mathrm{m}$ ), requires no sample preparation and is extremely fast and, thus, enables very high sample throughput. In return, the analytical precision is much lower than for conventional ${ }^{230} \mathrm{Th} / \mathrm{U}$-ages (a few percent compared to epsilon levels).

In undisturbed natural materials with an age of several million years, the activity of the parent (i.e. ${ }^{238} \mathrm{U}$ ) and the daughter isotopes (i.e. ${ }^{234} \mathrm{U}$ and ${ }^{230} \mathrm{Th}$, respectively) is in secular equilibrium. This state of equilibrium, however, can be disturbed by several natural processes, which is the basic principle of all U-series disequilibrium dating methods. In aqueous environments, the major reason for disequilibrium between $\mathrm{U}$ and $\mathrm{Th}$ is the different geochemical behaviour of the two elements. Whereas $U$ is soluble, Th is insoluble in natural waters and, thus, mainly transported adsorbed onto particles. As a consequence, groundwater, rivers, lakes and seawater contain significant amounts of dissolved U, but essentially no Th. During formation of secondary carbonates, $\mathrm{U}$ is thus incorporated, whereas $\mathrm{Th}$ is not. Consequently, secular equilibrium is disturbed, and the initial activity of ${ }^{230} \mathrm{Th}$ is zero. If the decay system remains closed after deposition (i.e. no $\mathrm{U}$ and $\mathrm{Th}$ isotopes are lost or added subsequently), the activity ratios of $\left({ }^{234} \mathrm{U} /{ }^{238} \mathrm{U}\right)$ and $\left({ }^{230} \mathrm{Th} /{ }^{238} \mathrm{U}\right)$ return to the state of secular equilibrium (e.g. Bourdon et al., 2003, activity ratios are indicated in parentheses in the following). The temporal evolution of the activity ratios (in particular the increase of ${ }^{230} \mathrm{Th}$ due to the decay of ${ }^{234} \mathrm{U}$ and ${ }^{238} \mathrm{U}$ ) allows dating of the time of carbonate formation (i.e. the timing of the establishment of disequilibrium) and, thus, the age of the carbonate phase. This is, however, only possible if two basic requirements are fulfilled: (i) no presence of initial ${ }^{230} \mathrm{Th}$ and (ii) the system remained closed after deposition. If one of these assumptions is violated, the resulting ${ }^{230} \mathrm{Th} / \mathrm{U}$-age may be substantially inaccurate.

${ }^{230} \mathrm{Th} / \mathrm{U}$-dating can, in principle, be applied to all materials whose formation is accompanied by a constrained disequilibrium between $\mathrm{U}$ and $\mathrm{Th}$. The materials most widely dated by the ${ }^{230} \mathrm{Th} / \mathrm{U}-\mathrm{method}$ are fossil reef corals and speleothems (Scholz and Hoffmann, 2008; Edwards et al., 2003), which can, in general, be accurately and precisely dated up to an age of $600 \mathrm{ka}$. However, with increasing sensitivity of both LA and MC-ICPMS systems, increasing precision may be achieved enabling high-precision in situ ${ }^{230} \mathrm{Th} / \mathrm{U}$-dating (i.e., without prior sample preparation) at very high spatial resolution. This may be particularly useful for impure carbonates found in fluvial deposits in order to analyse the most pristine fractions of a dirty sample. Examples of successful dating of inclusions in fluvial deposits by the ${ }^{230} \mathrm{Th} / \mathrm{U}$-method (Fig. 2) include pedogenic carbonates and calcretes 
deposited in alluvial fans and river terraces (e.g. Candy et al., 2004; Kelly et al., 2000; Ludwig and Paces, 2002; Sharp et al., 2003) as well as tufa and travertine (Schulte et al., 2008; Candy and Schreve, 2007). All these deposits have in common that they form subsequently to the deposition of fluvial sediments, such as fans and terraces (Fig. 2). Thus, they can only provide a minimum age for the fluvial deposits with which they are associated (Blisniuk et al., 2012). Carbonates that have been mobilised subsequent to deposition (e.g. flood events or washed in from slopes, Fig. 2) are not expected to provide reliable ${ }^{230} \mathrm{Th} / \mathrm{U}$-ages because they are (i) most likely affected by post-depositional diagenesis and (ii) difficult to relate to a depositional context (Fig. 2). Extensive reviews of the ${ }^{230} \mathrm{Th} / \mathrm{U}$-dating methodology can be found in the classic books by Ivanovich and Harmon (1992) and Bourdon et al. (2003).

\section{1. ${ }^{230} \mathrm{Th} / \mathrm{U}$-dating of secondary carbonates in fluvial archives: main issues}

In general, carbonates deposited in fluvial and lacustrine environments are difficult to date by the ${ }^{230} \mathrm{Th} / \mathrm{U}$-method. In many cases, samples of fluvial and lacustrine deposits contain very large amounts of detrital Th, which represents a violation of one of the basic requirements of the dating method. Since Th is mainly transported adsorbed onto particles, it is generally associated with relatively fast flowing water, which has the potential to transport these particles. In particular, carbonates associated with alluvial fans thus often contain substantial amounts of detrital Th (Fig. 2). However, pedogenic carbonates may also contain high amounts of detrital Th, which is mobilised from the overlying horizons (Fig. 2). These materials are thus often referred to as impure carbonates or dirty calcites (e.g., Kaufman, 1993). Initial Th is often associated with a silicate or clay fraction. Whereas the preparation of pure carbonate samples is relatively straightforward (e.g. Yang et al., 2015), the preparation of impure carbonates may be more elaborate due to the presence of an insoluble residue. Various approaches to deal with insoluble residues have been proposed (see Section 5.2.2). Initial (also often referred to as detrital) ${ }^{230} \mathrm{Th}$ is generally accompanied by ${ }^{232} \mathrm{Th}$, which is the most abundant naturally occurring isotope of Th. ${ }^{232} \mathrm{Th}$ does not occur in the decay chain of ${ }^{238} \mathrm{U}$ and is, in contrast to ${ }^{230} \mathrm{Th}$, not produced by the decay of ${ }^{234} \mathrm{U}$ and ${ }^{238} \mathrm{U}$. Elevated content of ${ }^{232} \mathrm{Th}$ is clear evidence for the presence of initial ${ }^{230} \mathrm{Th}$, and its concentration even provides a measure for the degree of contamination. For $\left({ }^{230} \mathrm{Th} /{ }^{232} \mathrm{Th}\right)$ activity ratios $<20$, a correction for detrital contamination is definitely required (Schwarcz, 1989). Other studies have suggested even higher thresholds for $\left({ }^{230} \mathrm{Th} /{ }^{232} \mathrm{Th}\right)$ necessitating a correction for detrital contamination (Richards and Dorale, 2003). Potential correction techniques that have been shown to be successful for fluvial deposits are discussed in Sections 5.2.1 and 5.2.2. In addition, post-depositional open-system behaviour is not uncommon for secondary carbonates deposited in fluvial environments, which is even more complicated to detect and account for (see 5.2.3.). For marine samples, such as corals, open system behaviour can be detected by comparing the initial $\left({ }^{234} \mathrm{U} /{ }^{238} \mathrm{U}\right)$ activity ratio of the sample with the $\left({ }^{234} \mathrm{U} /{ }^{238} \mathrm{U}\right)$ activity ratio of modern seawater (e.g. Edwards et al., 2003). In terrestrial environments, this is not possible due to the highly variable $\left({ }^{234} \mathrm{U} /{ }^{238} \mathrm{U}\right)$ activity ratio in river, lake and groundwater. Thus, successful ${ }^{230} \mathrm{Th} / \mathrm{U}$-dating of fluvial carbonates has been restricted to a relatively small number of case studies, which are characterised by the high $U$ content $\left({ }^{238} \mathrm{U}>1 \mu \mathrm{g} / \mathrm{g}\right)$ of the dated material.

\subsection{Approaches developed to date secondary carbonates by ${ }^{230} \mathrm{Th} / \mathrm{U}$}

Two general correction methods to account for detrital Th have been developed: a priori estimation of the $\left({ }^{230} \mathrm{Th} /{ }^{232} \mathrm{Th}\right)$ activity ratio of the detrital phase and isochron techniques. In rare cases, secondary carbonates associated with fluvial deposits, such as tufa and travertine, may be very clean, and a correction for initial ${ }^{230} \mathrm{Th}$ may not be necessary. For instance, Schulte et al. (2008) established a chronology for the fluvial terrace sequence from the River Aguas basin, Iberian Peninsula, by ${ }^{230} \mathrm{Th} / \mathrm{U}$-dating of travertine. The $\left({ }^{230} \mathrm{Th} /{ }^{232} \mathrm{Th}\right) \mathrm{ac}-$ tivity of some of their samples is larger than 20 , and a correction for initial ${ }^{230} \mathrm{Th}$ is not required. Candy and Schreve (2007) obtained ${ }^{230} \mathrm{Th} / \mathrm{U}$-ages on fluvial and colluvial tufa deposits from southern England with sufficient precision to correlate discrete periods of temperate climate with individual warm sub-stages during MIS 7. Although the $U$ content of their samples is relatively low (ca. $0.1 \mu \mathrm{g} / \mathrm{g}$ ), the $\left({ }^{230} \mathrm{Th} /{ }^{232} \mathrm{Th}\right)$ activity of the majority of samples is $>20$.

\subsubsection{A priori estimation of the $\left.\left({ }^{230} \mathrm{Th}\right)^{232} \mathrm{Th}\right)$ activity ratio of the detrital phase}

The average ${ }^{232} \mathrm{Th} /{ }^{238} \mathrm{U}$ weight ratio of the upper continental crust is 3.8 (Wedepohl, 1995). Assuming secular equilibrium between ${ }^{230} \mathrm{Th},{ }^{234} \mathrm{U}$ and ${ }^{238} \mathrm{U}$ for the detrital component, the $\left({ }^{230} \mathrm{Th} /{ }^{232} \mathrm{Th}\right)$ activity ratio of the initial Th is $\sim 0.9$ (Hellstrom, 2006). Based on the measured content of ${ }^{232} \mathrm{Th}$, the amount of initial (detrital) ${ }^{230} \mathrm{Th}$ can thus be estimated and subtracted from the measured concentration of ${ }^{230} \mathrm{Th}$. This approach is often referred to as a priori estimation of the detrital phase and may provide reasonable ages. However, the initial $\left({ }^{230} \mathrm{Th} /{ }^{232} \mathrm{Th}\right)$ activity ratio is highly variable and associated with large uncertainties. Usually, an uncertainty of $50 \%$ is assumed (Hellstrom, 2006). Propagation of this substantial uncertainty to the corrected ${ }^{230} \mathrm{Th} / \mathrm{U}$-age may lead to highly elevated age uncertainties and even ages with zero significance (Kaufman, 1993; Wenz et al., 2016). Despite these large uncertainties, a priori estimation of the $\left({ }^{230} \mathrm{Th} /{ }^{232} \mathrm{Th}\right)$ activity ratio of the detrital phase has been successfully applied to date fluvial deposits by the ${ }^{230} \mathrm{Th} / \mathrm{U}$-method. For instance, Adamson et al. (2014) obtained a large number of ages for fluvial deposits in Montenegro by ${ }^{230} \mathrm{Th} / \mathrm{U}$-dating of carbonate benches and calcite rinds. This study is particularly remarkable because the $U$ content of the studied samples was relatively low $(<1 \mu \mathrm{g} / \mathrm{g})$. However, many samples also have very low ${ }^{232} \mathrm{Th}$, resulting in $\left({ }^{230} \mathrm{Th} /{ }^{232} \mathrm{Th}\right)$ activity ratios $>20$. Ludwig and Paces (2002) determined ${ }^{230} \mathrm{Th} / \mathrm{U}$-ages on pedogenic silica-carbonate clast rinds and matrix laminae from alluvium in Crater Flat, Nevada, employing the TSD-technique, whereas Sharp et al. (2003) dated pedogenic carbonate clast-rinds from gravels of glacio-fluvial terraces in the Wind River Basin, Wyoming. The success of both studies is mainly based on the high $U$ content of the samples. Blisniuk and Sharp (2003) determined the age of two well-preserved fluvial terrace surfaces in central Tibet by ${ }^{230} \mathrm{Th} / \mathrm{U}$-dating of pedogenic carbonate rinds on clasts in the terrace deposits.

\subsubsection{Isochron methods}

The second approach to account for initial or detrital ${ }^{230} \mathrm{Th}$ is the isochron methodology. For isochron ${ }^{230} \mathrm{Th} / \mathrm{U}$-dating of impure carbonates, various procedures for sample preparation have been proposed (e.g. total sample dissolution (TSD), leachate-leachate (L/L), leachate-residue (L/R), Bischoff and Fitzpatrick, 1991; Kaufman, 1993; $\mathrm{Ku}$ and Liang, 1984; Luo and Ku, 1991; Schwarcz and Latham, 1989). In addition, several statistical methods for the evaluation of the isochron data have been developed (Ludwig, 2003). In general, 
the isochron method is more flexible than the a priori approach and provides more reliable ages with smaller uncertainties (Wenz et al., 2016). However, the application of the isochron methodology is based on two assumptions: all sub-samples (i) must have the same age and (ii) should contain different amounts of the same detrital component (i.e. with the same $\left({ }^{234} \mathrm{U} /{ }^{238} \mathrm{U}\right)$ and $\left({ }^{230} \mathrm{Th} /{ }^{238} \mathrm{U}\right)$ ratios). Unfortunately, the latter assumption in particular is not fulfilled for many impure carbonate samples (Ludwig, 2003; Wenz et al., 2016), again leading to large age uncertainties and corrected ages with low significance. Isochron techniques have also been successfully applied for ${ }^{230} \mathrm{Th} /$ U-dating of fluvial deposits. For instance, a stratigraphically consistent chronology based on isochron ${ }^{230} \mathrm{Th} / \mathrm{U}$-ages determined on pedogenic calcretes has been reported for alluvial terrace sequences from the Sorbas Basin, south-eastern Spain (Candy et al., 2004, 2005; Kelly et al., 2000). However, Candy et al. (2005) have shown that dating of mature calcretes is much more difficult than dating of immature calcretes, as has been revealed by the isochron statistics. Nevertheless, it may also be possible to determine a reliable age for mature calcretes if a large number of sub-samples from a single horizon are dated. Other studies aiming to date fluvial deposits were not successful in accounting for initial ${ }^{230} \mathrm{Th}$ by isochron techniques. For instance, Kock et al. (2009) attempted ${ }^{230} \mathrm{Th} / \mathrm{U}$-dating of pedogenic carbonate crusts from fluvial gravels of the River Rhine, and compared them with internally coherent OSL ages. Most of their U-series data scattered widely on isochron diagrams suggesting multiple components of initial ${ }^{230} \mathrm{Th}$ that are not related to detrital ${ }^{232} \mathrm{Th}$. A significant fraction of the initial ${ }^{230} \mathrm{Th}$ may originate from bacterial activity and Th transport on organic colloids. This suggests that samples in which bacteria could have contributed to carbonate precipitation should be avoided.

\subsubsection{Accounting for open-system behaviour}

One option for detecting open-system behaviour of ${ }^{230} \mathrm{Th} / \mathrm{U}$-ages of fluvial deposits is through comparison with independent ages (e.g. Blisniuk et al., 2012; see Section 7). Another option is consideration of the stratigraphical context of the deposited samples, i.e. whether the determined (corrected) ${ }^{230} \mathrm{Th} / \mathrm{U}$-ages are in stratigraphical order within a sedimentary sequence. This approach is currently used to identify ages representing outliers, probably because the applied correction techniques were not successful or due to post-depositional open-system behaviour. This approach has been proved to be successful for the aragonitic lacustrine sediments from Lake Lisan, the Last Glacial precursor of the Dead Sea, which have been extensively studied by ${ }^{230} \mathrm{Th} /$ U-dating (e.g., Torfstein et al., 2013). These sediments contain high amounts of $U(>3 \mu \mathrm{g} / \mathrm{g})$, and different approaches have been used to obtain corrected ages, including isochrons (Schramm et al., 2000), $a$ priori estimates of the detrital $\left({ }^{230} \mathrm{Th} /{ }^{232} \mathrm{Th}\right)$ activity ratio (Schramm et al., 2000) and an iterative approach independently evaluating the composition of the detrital component for every set of coeval samples (Torfstein et al., 2013). Furthermore, several authors recently have suggested algorithms for speleothems including stratigraphical constraints in order to estimate the $\left({ }^{230} \mathrm{Th} /{ }^{232} \mathrm{Th}\right)$ activity ratio of the detrital component (Hellstrom, 2006; Roy-Barman and Pons-Branchu, 2016). These algorithms may also be very useful for fluvial samples deposited in a clear stratigraphical context.

\section{Terrestrial cosmogenic nuclides (TCN) dating of fluvial deposits}

The development of the AMS technology in the early 1980s (e.g. Klein et al., 1982), which allowed measurements of isotopic ratios as low as $10^{-15}$ at that time (presently $10^{-16}$ has been reached), represented a decisive milestone, enabling the use of TCN as a dating tool, as proposed by Davis and Schaeffer (1955). In parallel, a tremendous amount of work has taken place and aimed at understanding the physical properties and processes involved in the production of the most commonly used nuclides in the Earth sciences, i.e. ${ }^{3} \mathrm{He},{ }^{10} \mathrm{Be},{ }^{21} \mathrm{Ne}$, ${ }^{26} \mathrm{Al}$ and ${ }^{36} \mathrm{Cl}$ (e.g. Nishiizumi et al., 1986; see reviews of Gosse and Phillips, 2001; Dunai, 2010). A particular emphasis was on the determination and refinement of their respective production rates according to the different production pathways, mostly involving fast neutron(spallation) and muon-induced reactions (Gosse and Phillips, 2001). This is well exemplified by the strongly debated determination of both the production rate of ${ }^{10} \mathrm{Be}$ in quartz and the half-life of this radionuclide (Gosse and Phillips, 2001; Dunai, 2010). Moreover, the use of these nuclides as geochronometers required integrating the variability of production rates in space and time, hence the build-up of scaling factors (Dunai, 2010).

Depending on the aim of the study and/or the fluvial or lacustrine environment where it takes place, numerical ages based on concentration measurements of cosmogenic nuclides can be undertaken either via surface exposure dating or burial dating (Fig. 2). Both dating approaches are presented in this section. Note that the material that has to be dated undergoes pre-exposure to cosmic rays during (i) bedrock exhumation, (ii) temporary storage on hillslopes and (iii) transport and/ or temporary storage in the fluvial system (Fig. 2). This accumulation of cosmogenic nuclides inventories prior to the depositional event is known as inheritance (Anderson et al., 1996). Whereas surface exposure dating of depositional landforms is highly sensitive to this process (see 6.1), this inherited component allows the dating of a burial event (see 6.2). In fluvial settings, surface exposure dating first provided numerical ages for alluvial fans (Siame et al., 1997; Van der Woerd et al., 1998) and river terraces, both bedrock strath terraces (Burbank et al., 1996; Leland et al., 1998) and alluvium-mantled terraces (Anderson et al., 1996; Repka et al., 1997). In lacustrine environments, surface exposure dating of palaeo-shorelines provides information about former lake-level highstands (Rades et al., 2013). Burial dating can be applied to in cave-deposited alluvium (Granger et al., 1997) or deeply buried fluvial or lacustrine sediments (Kong et al., 2009).

\subsection{Surface exposure dating}

The calculation of exposure ages requires both high-precision AMS measurements of nuclide concentrations and the determination of the site-specific nuclide production rate. The latter must integrate the use of specific scaling factors and the potential topographic or self shielding of cosmic rays at the sampling location (Dunai, 2010). As fluvial sediments or related landforms very often contain quartz-bearing material, surface exposure ages are usually determined via concentration measurements of ${ }^{10} \mathrm{Be}$ (Fig. 7a, Dunai, 2010), sometimes used alongside ${ }^{26} \mathrm{Al}$ (e.g. Repka et al., 1997; Rixhon et al., 2011). However, alternative nuclide species are produced in other minerals, such as ${ }^{3} \mathrm{He}$ in olivine and pyroxene or ${ }^{36} \mathrm{Cl}$ in calcite (see Gosse and Phillips, 2001; Dunai, 2010), thereby allowing other lithologies to be dated (e.g. Baynes et al., 2015). The dateable range in surface exposure dating of fluvial environments varies strongly according to the setting and the employed nuclide(s) (Fig. 1). The lower age range very much depends on the detection limit of the AMS, hence the production rates, but late Holocene exposure ages of bedrock strath surfaces were obtained (Leland et al., 1998, see 6.1.2.). On the other hand, surface exposure dating with ${ }^{10} \mathrm{Be}$, because of its long half-life (i.e. $\sim 1.36 \mathrm{Ma}$ ), permits pre-Quaternary ap- 

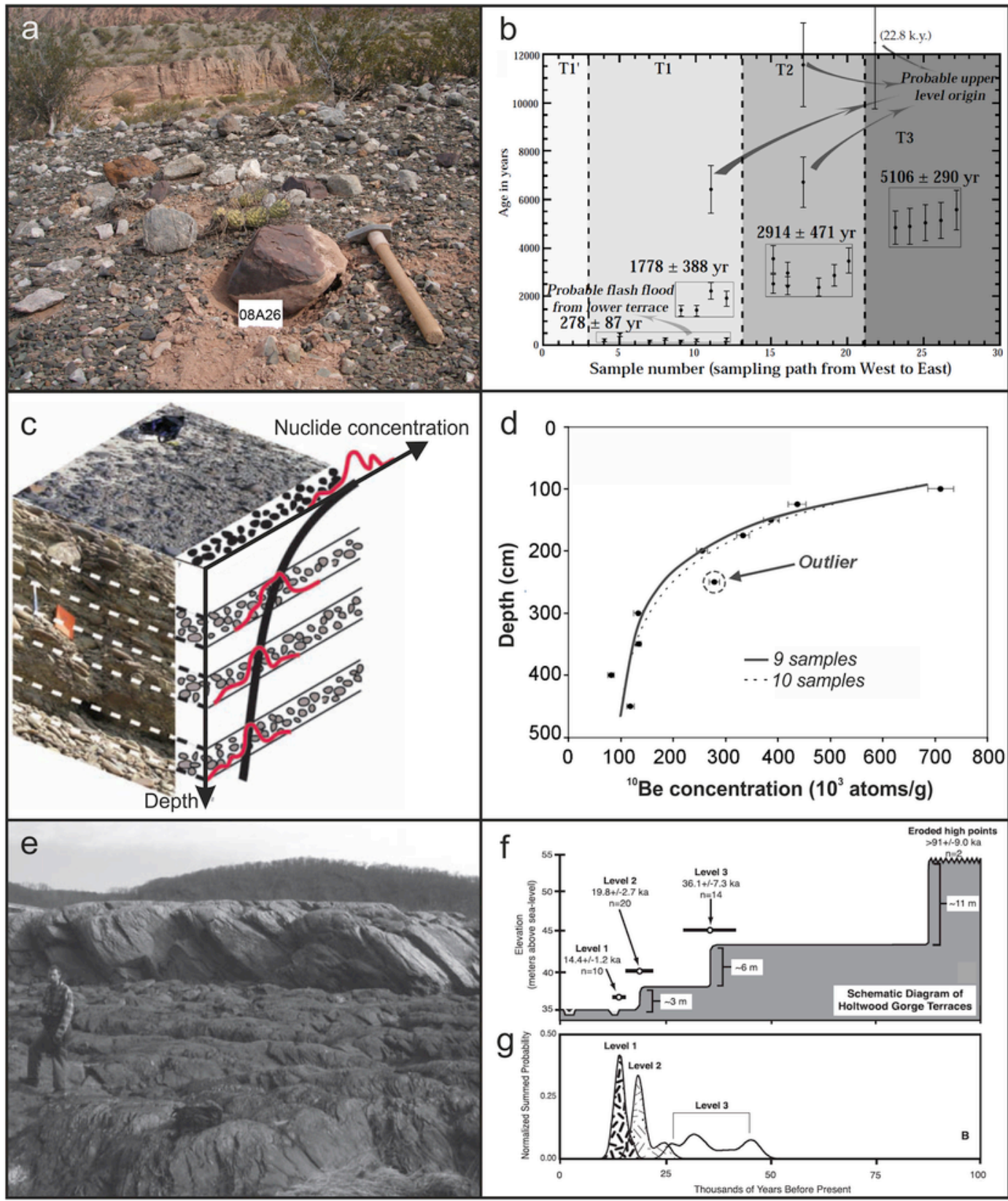

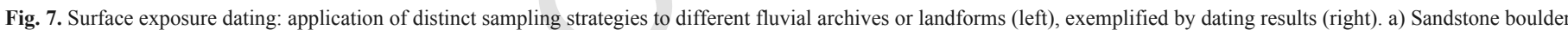

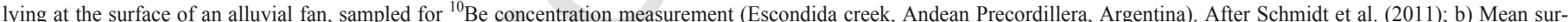

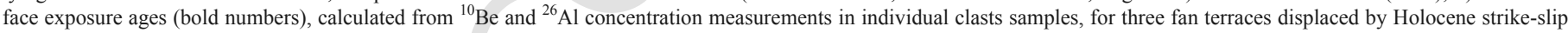

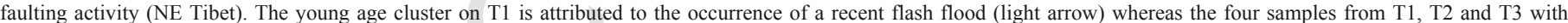

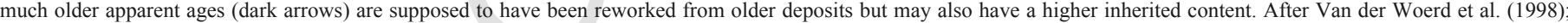

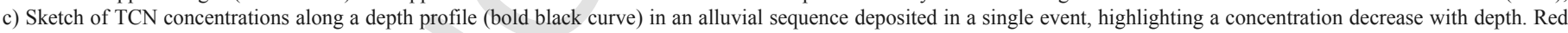

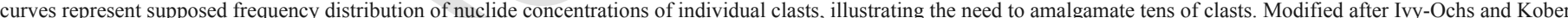

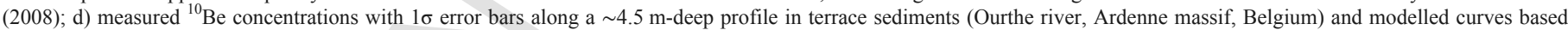

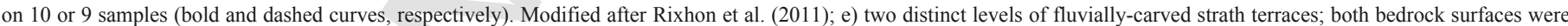

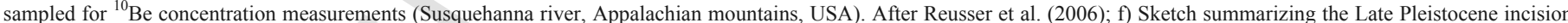

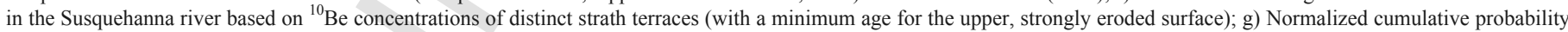

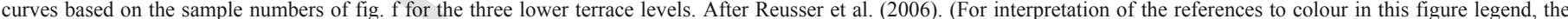
reader is referred to the web version of this article.)

plications under specific conditions without saturation being reached (Dunai, 2010).

In many instances, surface exposure ages of fluvial depositional surfaces, especially alluvial fans, were formerly based on concentration data obtained from individual clasts or boulders lying on these
(Fig. 7a, b; e.g. Siame et al., 1997; Van der Woerd et al., 1998). However, Schmidt et al. (2011) emphasized the need of caution when inferring exposure ages from such TCN concentration data; diverse geomorphological processes acting on a surface might indeed represent a considerable source of uncertainty. These encompass inher- 
itance (Fig. 2), post-depositional weathering, erosion or covering by sediments and even by snow (e.g. Anderson et al., 1996; Rixhon et al., 2011). Whereas inheritance might lead to an overestimate of the true exposure age, all other processes tend to reduce the cosmogenic inventory near the dated surfaces and thereby result in age underestimations. An unequal distribution and/or intensity of these stochastic processes across the surface might result in a significant spread in apparent exposure ages (Owen et al., 2014). For this reason thorough field observations and descriptions are an absolute prerequisite for surface exposure sampling (see field template in Dunai, 2010).

\subsubsection{Depth profile dating of depositional surfaces (alluvial fans, alluvium-mantled terraces)}

The depth profile sampling technique may overcome some of the uncertainties related to these geomorphological processes (Anderson et al., 1996). It allows simultaneous computation of exposure time (i.e. the abandonment time of the landform), the post-depositional denudation rate of the landform and inheritance (Braucher et al., 2009; Hidy et al., 2010). This approach consists of sampling the fluvial sediments at regular depth intervals (Fig. 7c), taking advantage of the spallation-dominated production at or near the surface and the muon-dominated production at greater depth (Braucher et al., 2009). Given the physical properties of these particles, an exponential decrease of TCN concentrations along the depth profile is expected and can be modelled by Monte Carlo simulations (Fig. 7d, see the user-friendly simulator of Hidy et al., 2010). However, because this method is very sensitive to any post-depositional reworking processes (e.g. cryo or bioturbation ...), one should avoid sites where such processes have occurred.

The depth profile technique is particularly useful for dating alluvial fans and fill terraces (Fig. 7d, e.g. Repka et al., 1997; Le Dortz et al., 2011; Rixhon et al., 2011). In contrast to the pioneering studies on alluvial fans (e.g. Siame et al., 1997), almost all recent works systematically combined surface concentration data with depth profile data to better constrain the inheritance and the post-depositional evolution of the landform (e.g. Le Dortz et al., 2011; Schmidt et al., 2011; Owen et al., 2014). Where the petrographic composition of fan - or terrace - sediments is favourable, it is advisable to perform an internal control by comparing concentrations of different nuclides. For instance, quartz-bearing and calcite-bearing materials enable ${ }^{10} \mathrm{Be}$ and ${ }^{36} \mathrm{Cl}$ concentration measurements, respectively (Le Dortz et al., 2011). As lateral or vertical offsets disrupting fan surfaces represent an excellent geomorphological marker for crustal deformation, surface exposure ages allow quantifying average slip rates along main fault lines for the Middle/Late Pleistocene and/or the Holocene (e.g. Siame et al., 1997; Le Dortz et al., 2011). Also, surface exposure dating of fan surfaces may likewise provide valuable information about climatic forcing on fan formation (e.g. Owen et al., 2014). Depth profile concentration data of terrace sediments are commonly used to quantify incision rates by sampling vertically-spaced levels within terrace sequences (e.g. Repka et al., 1997). Alternatively, diachronic abandonment times of geometrically-correlated terraces along a hydrological network allow inference of long-term propagation rates of a specific incision wave from the main trunk into its (sub-)tributaries (Rixhon et al., 2011).

\subsubsection{Surface exposure dating of strath terraces}

An alternative application of the surface exposure method consists of dating bedrock surfaces of strath terraces (Fig. 2). This term is used here to describe laterally-carved benches in steep valley flanks, especially in actively uplifting orogens (e.g. Himalayas), and are often characterised by smooth polished surfaces or sculpted erosional features (Fig. 7e, Burbank et al., 1996; Leland et al., 1998). Inheritance usually does not represent a major issue for strath terraces since they are erosional landforms. Provided that the bedrock surface is still pristine, one can assume insignificant weathering or erosion after strath abandonment. If the strath was not covered by temporary alluvium or landslide deposits subsequent to terrace abandonment (see Leland et al., 1998), the calculation of the exposure time is straightforward (Fig. 7f, g). To check the representativeness of bedrock samples and to take concentration variability into account, we recommend the nested sampling strategy of Reusser et al. (2006). The thin alluvial cover can also be sampled if it is present (e.g. Reusser et al., 2006). Surface exposure dating of strath terraces in diverse gorge settings highlighted, for instance, (i) differential rock uplift related to major thrust activity in active orogens (Burbank et al., 1996; Leland et al., 1998), (ii) regional, climatically-driven incision of rivers along a passive margin (Fig. 7f, g, Reusser et al., 2006) or (iii) the impact of extreme flood events for canyon formation related to significant knickpoint retreat (Baynes et al., 2015).

\subsection{Burial dating}

In contrast to surface exposure dating, which relies on continuous accumulation of TCN, burial dating is based on the differential decay of at least two nuclides, where at least one of them is a radionuclide - for full details, see Granger and Muzikar (2001) and Granger (2014). The nuclide pair ${ }^{26} \mathrm{Al} /{ }^{10} \mathrm{Be}$ is frequently employed because they are both produced in quartz and their production ratio is fundamentally independent from latitude and altitude and varies only slightly with depth (Dunai, 2010; Granger, 2014). In the case of the pair ${ }^{26} \mathrm{Al}$ and ${ }^{10} \mathrm{Be}$, burial dating is based on a two step exposure/ shielding episode of any quartz-bearing material. First, the latter accumulates nuclide inventories during exhumation of bedrock and transport/storage on hillslopes and in the drainage network (Fig. 2), i.e. the inherited component. Whilst the amount of both nuclides in any given clast or grain is impossible to predict due to stochastic individual exposure history, ${ }^{10} \mathrm{Be}$ and ${ }^{26} \mathrm{Al}$ concentrations are related as they are produced in the same material over the same time period, resulting in $\mathrm{a}^{26} \mathrm{Al} /{ }^{10} \mathrm{Be}$ surface concentration ratio of $\sim 6.75: 1$ (Dunai, 2010; Granger, 2014). Second, the quartz-bearing material is rapidly buried (see Section 6.2.1.), implying a cessation of production (Fig. 2). Exploiting the differential radioactive decays of both nuclides, the preburial ratio decreases with increasing burial duration according to the corresponding half-lives of each nuclide (Dunai, 2010). The time range of application of burial dating extends into the Pliocene ( up to $5 \mathrm{Ma}$; Fig. 1) but the current analytical precision of ${ }^{26} \mathrm{Al}$ measurements in AMS implies uncertainties of (at least) 60-100 ka (Dunai, 2010; Granger, 2014).

\subsubsection{Complete and fast burial: dating of in cave-deposited alluvium}

Fast and complete burial of sediments requires two basic assumptions (Granger and Muzikar, 2001). First, the time span over which incomplete shielding occurs is much shorter than the subsequent burial duration. Second, shielded sediments are buried sufficiently deeply, i.e. in practice $\geq 30 \mathrm{~m}$, implying an insignificant production through muons at depth. Given that these prerequisites are frequently met for in-cave deposited alluvium (Fig. 2), the sampling of these sediments is one of the most straightforward applications of burial dating (Dunai, 2010). River sediments washed into abandoned phreatic tubes in limestone valley walls characterize the last time the passage was at the local water table (Fig. 8a, Anthony and Granger, 2007). Alluvium-filled multi-level cave systems thus mimic alluvium-mantled terrace staircases and, as such, also record the re- 


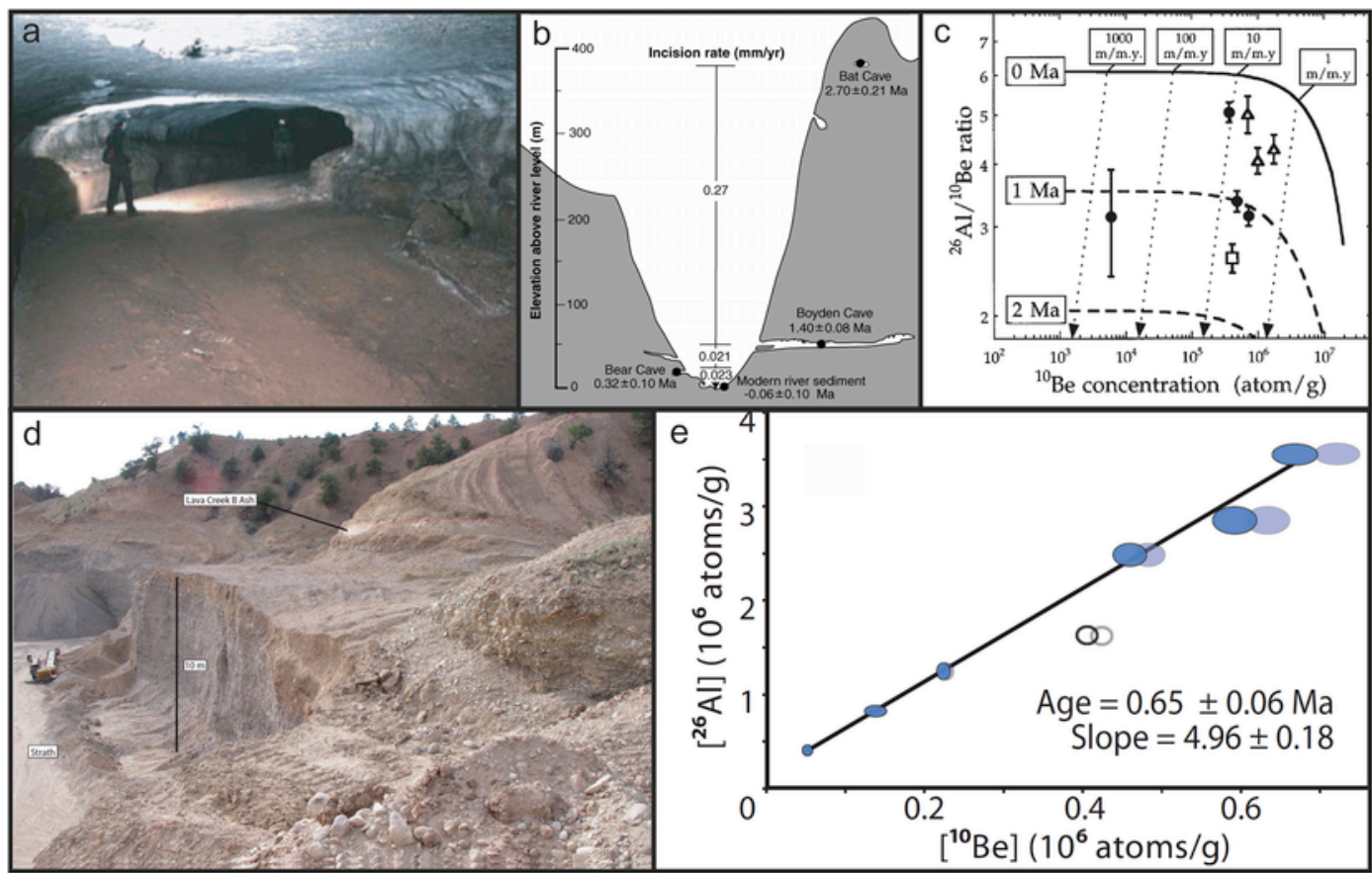

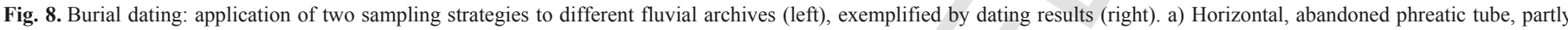

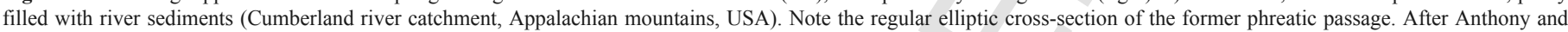

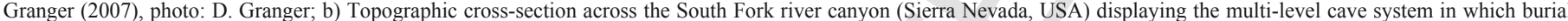

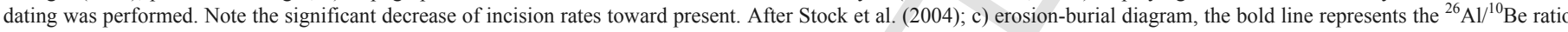

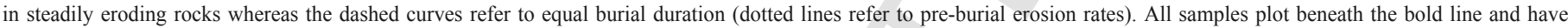

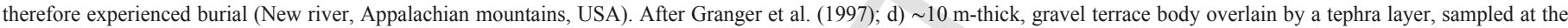

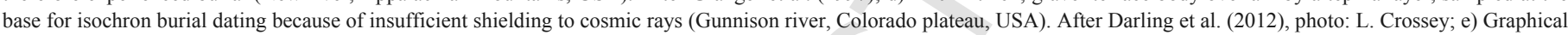

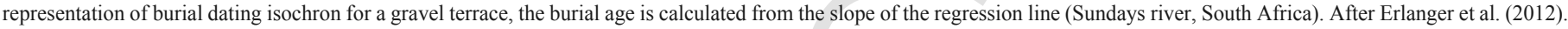

gional incision history of river systems (Fig. 8b, Anthony and Granger, 2007). The selection of suitable sampling sites should ensure that abandoned and alluvium-filled phreatic tubes were not contaminated by any reworked material from an older (or younger) depositional episode (Dunai, 2010). The solution of the complete and fast burial dating equations is graphically expressed on the so-called erosion-burial diagram, where the ${ }^{26} \mathrm{Al} /{ }^{10} \mathrm{Be}$ ratio is plotted against ${ }^{10} \mathrm{Be}$ concentrations (Fig. 8c). This approach has provided valuable new insights into long-term incision rates in diverse tectonically-active (Fig. 8 b, e.g. Stock et al., 2004) and moderately-uplifted (e.g. Granger et al., 1997; Anthony and Granger, 2007) settings, or in river catchments marked by enhanced glacial deepening (Häuselmann et al., 2007).

\subsubsection{Overcoming incomplete shielding: isochron burial dating of fill terraces}

The $\geq 30 \mathrm{~m}$ overburden thickness as a prerequisite for a complete shielding is unfortunately not often met in cases of river terraces, even in thick fill terraces (Fig. 8d). In these instances, incomplete shielding of the fluvial sediment to the cosmic rays may imply significant postburial production through deeply-penetrating muons (Granger and Muzikar, 2001). As postburial production is very difficult to constrain, it may become a considerable issue to produce reliable burial ages. This problem was overcome by the isochron burial dating method (Balco and Rovey, 2008), which involves the sampling of several pebbles from the same stratigraphical layer at the base of the river terrace (Erlanger et al., 2012; Darling et al., 2012). It relies on the fact that these clasts are likely to have originated from different source areas in the catchment (Erlanger et al., 2012). As the latter is subject to variable production and/or surface erosion rates, and clasts have variable transport and/or storage time within the fluvial system, they have distinct pre-burial histories resulting in different ${ }^{10} \mathrm{Be}$ and ${ }^{26} \mathrm{Al}$ inherited concentrations. Sampling the same stratigraphical layer implies an identical postburial production for each of them; this parameter can thus be treated as a constant among samples (Erlanger et al., 2012). On the graphical representation of isochron burial dating $\left({ }^{26} \mathrm{Al}\right.$ concentration plotted against ${ }^{10} \mathrm{Be}$ concentration), the burial age is calculated from the slope of the regression line (Fig. 8e). Used on a well-preserved terrace flight in South Africa (Sundays River), this approach yielded valuable terrace ages for inferring Late Cenozoic incision rates (Erlanger et al., 2012).

\subsection{Future potential of TCN dating}

In addition to the commonly employed $\mathrm{TCN}\left({ }^{3} \mathrm{He},{ }^{10} \mathrm{Be},{ }^{21} \mathrm{Ne},{ }^{26} \mathrm{Al}\right.$ and ${ }^{36} \mathrm{Cl}$ ), the use of further radionuclides may extend the application time span of TCN. On the one hand, the long-lived ${ }^{53} \mathrm{Mn}$ nuclide, given its half-life of $3.7 \pm 0.4 \mathrm{Ma}$, has the potential to unravel exposure histories older than $10 \mathrm{Ma}$ in iron-bearing materials, although it requires AMS technologies with higher energies than those presently attained in order to reduce the analytical uncertainty (Schaefer et al., 2006). On the other hand, in situ-produced ${ }^{14} \mathrm{C}$, with its short half-life, is able to reveal short-term sediment storage time within large floodplains (Hippe et al., 2012). These values can be compared with long-term estimates of sediment production when they are used in combination with ${ }^{10} \mathrm{Be}$ and ${ }^{26} \mathrm{Al}$ (Hippe et al., 2012). Also, coupling ${ }^{21} \mathrm{Ne}$ concentrations with the nuclide pair ${ }^{10} \mathrm{Be}$ and ${ }^{26} \mathrm{Al}$, all measured in the same quartz-bearing material, improves both 
the accuracy and the time range of ${ }^{26} \mathrm{Al} /{ }^{10} \mathrm{Be}$ burial dating (Balco and Shuster, 2009).

\section{Application of multiple numerical dating methods to single fluvial sequences}

In this contribution, we have focused on the major recent developments of five numerical dating techniques and showed how these have enabled new dating applications in diverse fluvial settings at different time scales. However, two main recommendations must be borne in mind. First, there is no ideal numerical dating method that can provide accurate age results on any kind of sample and in any context. The use of a dating method, even the most established one such as ${ }^{14} \mathrm{C}$, is limited by a range of intrinsic constraints and based on some implicit assumptions. Because the latter are rarely openly stated, expectations regarding numerical dating methods from non-geochronologists are sometimes unreasonable. Setting more realistic expectations from non-specialists is a key aim of this paper. Second, each method presented here, when applied to fluvial archives or landforms, may encounter specific methodological issues. This, in turn, may bias the "true" age of the event that has to be dated: for instance, age overestimation of a fluvial depositional event may be caused by the reworking of organic material $\left({ }^{14} \mathrm{C}\right)$, incomplete bleaching of the quartz dosimeter (OSL and ESR), inaccurate estimation of the initial $\left({ }^{230} \mathrm{Th} /{ }^{232} \mathrm{Th}\right)$ activity ratio $\left({ }^{230} \mathrm{Th} / \mathrm{U}\right)$ or inherited nuclide concentrations $(\mathrm{TCN})$.

To overcome some of these limitations, we therefore strongly recommend applying three different approaches. Each of these is exemplified by case studies, including a discussion how the combination of these dating methods may strengthen the chronological framework of fluvial archives. First, provided that the petrographic composition of the fluvial sediments is favourable, some of these dating methods may allow an internal cross-check. For instance, surface exposure ages are strengthened when ${ }^{10} \mathrm{Be}$ concentrations are measured alongside ${ }^{36} \mathrm{Cl}$ concentrations from quartz-bearing and calcite-bearing material, respectively (e.g. Le Dortz et al., 2011). The same holds for luminescence dating: Colarossi et al. (2015) comparatively analysed OSL (quartz) and post-IR IRSL (feldspar) signals from identical samples collected in Quaternary river sediments (South Africa) to test whether the second dosimeter can reliably date partially bleached sediments. Notwithstanding the statement that the post-IR IRSL 225 signal was the most adequate because of the fastest bleaching kinetics, age convergence and divergence were both observed for younger $(<20 \mathrm{ka})$ and older (>50 ka) samples, respectively (Colarossi et al., 2015). Further research is however required to understand the cause(s) of this discrepancy for older fluvial material.

Second, as stated by Brauer et al. (2014), it is of major importance to produce independent chronologies obtained from different dating methods, provided that the nature and the characteristics of the fluvial deposits allows it (e.g. Table 1). A common combination involves radiocarbon and OSL dating to yield robust chronologies for Late Pleistocene/Holocene fluvial sequences (e.g. de Moor et al., 2008). Moreover, age discrepancies between these two dating methods may give further insights into methodological issues. For instance, based on directly comparable paired OSL and ${ }^{14} \mathrm{C}$ ages of Late Pleistocene terrace deposits from Eastern England, Briant and Bateman (2009) showed that ages inferred from both methods are either consistent $(<29-35 \mathrm{ka})$ or divergent $(>29-35 \mathrm{ka})$ (Fig. 9a). The systematic age underestimation of ${ }^{14} \mathrm{C}$ dating beyond this limit is attributed to secondary contamination of older organic material by low levels of modern carbon (Fig. 3); it was thus suggested that conventionally pre-treated ${ }^{14} \mathrm{C}$ ages $\geq 29-35$ ka should be treated with great caution
(Briant and Bateman, 2009). Likewise, some of the case studies mentioned in this contribution take advantage of rarely used combinations between OSL, ESR, ${ }^{230} \mathrm{Th} / \mathrm{U}$ and TCN dating (Chaussé et al., 2004; Stock et al., 2005; Kock et al., 2009; Le Dortz et al., 2011; Blisniuk et al., 2012). For instance, Blisniuk et al. (2012) applied a combination of ${ }^{10} \mathrm{Be}$ exposure dating with ${ }^{230} \mathrm{Th} / \mathrm{U}$-dating to constrain the deposition of mid-Holocene to late Pleistocene alluvial fans (California). Three sampling strategies were implemented for the first method: top surface of individual large boulders (Fig. 7a), amalgamate of surface clasts and depth profile (Fig. 7c). The second method involved the sampling of post-depositional pedogenic carbonate from sub-surface clast-coatings. ${ }^{230} \mathrm{Th} / \mathrm{U}$ ages (minimum ages) are convergent or slightly younger than TCN ages (maximum ages if not corrected for inheritance and assuming zero denudation), thereby proving the usefulness of this combined approach in obtaining reliable depositional ages of fan deposits (Fig. 9b). Furthermore, the computing of ${ }^{10} \mathrm{Be}$ depth profile ages of Late Pleistocene alluvium was made easier by the valuable minimum age information inferred from ${ }^{230} \mathrm{Th} / \mathrm{U}$ dating (Fig. 9b).

Third, as well as the parallel use of two or more independent methods from the same fluvial sequences, a few exploratory studies have attempted to merge the dating principles of distinct methods. For instance, Guralnik et al. (2011) developed an innovative approach using a mathematical framework for consistently incorporating ${ }^{10} \mathrm{Be}$ concentration data along a depth profile with OSL ages from a single alluvial section (Fig. 9c, d). This model is based on three parameters and solves an integrated, co-dependent and self-consistent set of equations and assumes fluvial aggradation at a constant rate, with uniform cosmogenic inheritance, followed by terrace abandonment and subsequent preservation and exposure of its surface (Fig. 9c, d). This scenario of terrace evolution may be validated or rejected by comparing model depth concentration data and model OSL ages to real observations (Guralnik et al., 2011).

As a conclusion, establishing reliable chronologies for Quaternary fluvial sequences has strongly benefited from such applications of multiple dating methods. We finally recommend combining age results of numerical methods with chronological information obtained from relative dating methods. This is particularly well exemplified by the study of Antoine et al. (2007), synthesizing age results in the Somme valley (northern France), where diverse numerical $\left({ }^{14} \mathrm{C}\right.$, TL, IRSL, ESR, ${ }^{230} \mathrm{Th} / \mathrm{U}$ ) and relative (palaeomagnetism, mammalian biostratigraphy and amino-acid racemization) methods were implemented. In addition, control for ESR dating was internally provided by cross-checking results of optically bleached quartz grains with U-series/ESR dating of tooth enamel. This multi-dating approach enabled Antoine et al. (2007) to build a coherent and robust chronostratigraphical interpretation of the terrace sequence of the Somme valley for the last $1 \mathrm{Ma}$.

\section{Uncited references}

Arnold and Roberts, 2009; Duval and Guilarte Morene, 2012; Flez and Lahousse, 2015; Mathieu et al., 2015; Schmidt et al., 2015; Grün, 2000

\section{Acknowledgements}

M. Duval's research was funded by a Marie Curie International Outgoing Fellowship of the EU's Seventh Framework Programme (FP7/2007-2013), awarded under REA Grant Agreement No. PIOF-GA-2013-626474. D. Scholz acknowledges funding of the DFG (SCHO 1274/9-1). Two anonymous reviewers are ac- 

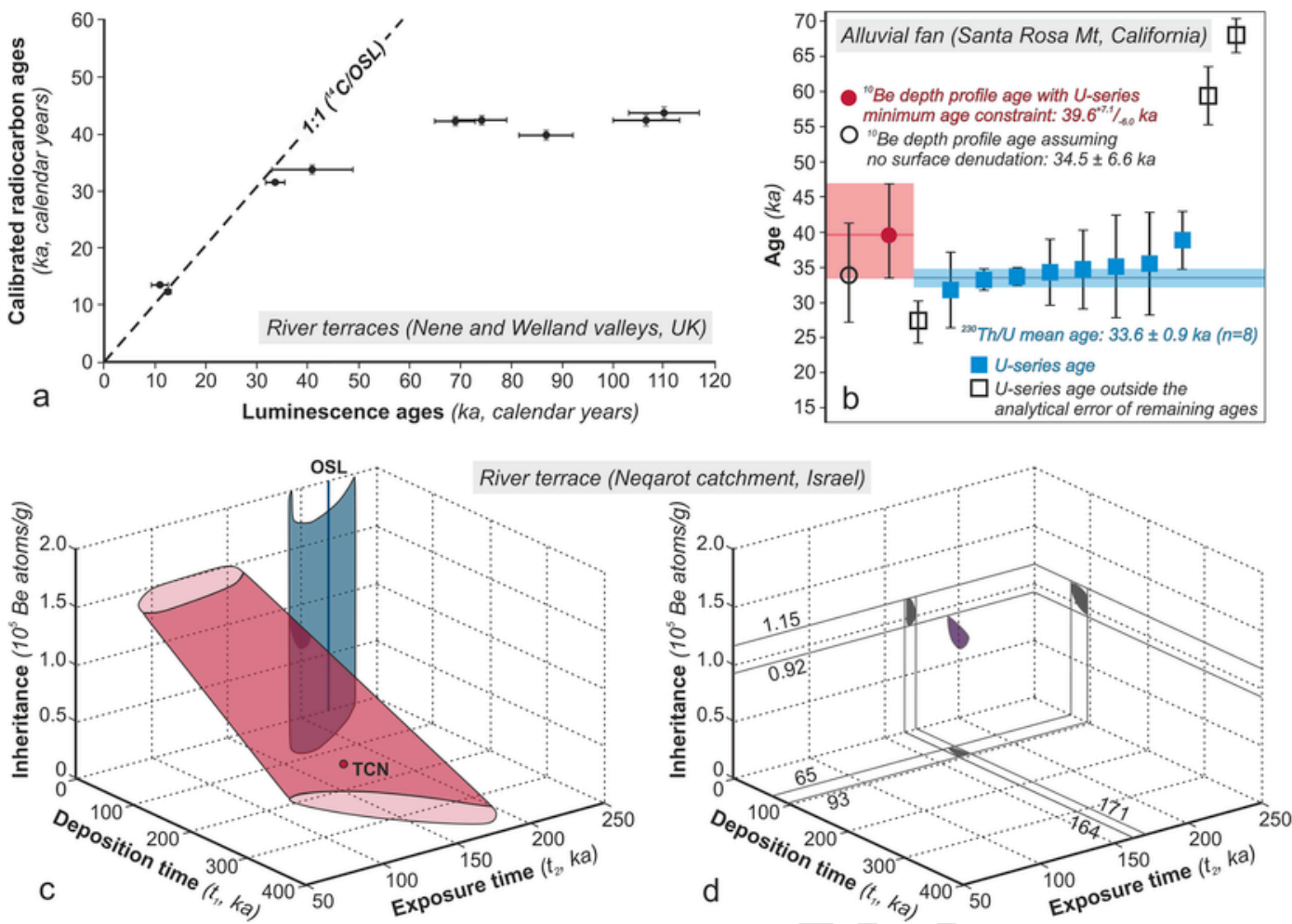

Fig. 9. a) Comparison of ${ }^{14} \mathrm{C}$ (uncertainties: one standard deviation) and OSL (uncertainties: one standard error) dates. Calibration of radiocarbon dates: Calib 5.0 (Stuiver et al, 2005 ) with the IntCal04 dataset (Reimer et al., 2004) for ages $<26{ }^{14} \mathrm{C}$ ka BP and Fairbanks et al. (2005) for ages $>26{ }^{14} \mathrm{C}$ ka BP. Note the systematic age underestimation of ${ }^{14} \mathrm{C}$ dating beyond the $29-35$ ka limit. After Briant and Bateman (2009). b) Plot showing ${ }^{10}$ Be depth profile ages and ${ }^{230} \mathrm{Th} / \mathrm{U}$ ages for alluvial fan deposits, both with $2 \sigma$ error. Shaded red and blue boxes represent the mean ${ }^{10} \mathrm{Be}$ exposure age and mean U-series age, respectively. Note the slightly younger age range of ${ }^{230} \mathrm{Th} / \mathrm{U}$ dating (minimum age) than the one defined by the depth profile, proving the usefulness of this combined approach. After Blisniuk et al. (2012). c, d) Integrated ${ }^{10} \mathrm{Be}$ depth profile and OSL model results in the model parameter space of deposition time $\left(t_{l}\right)$, exposure time $\left(t_{2}\right)$, and ${ }^{10} \mathrm{Be}$ inheritance for a single alluvial sequence. The cosmogenic nuclide model best fit (thick red dot) with the $68 \%$ confidence level envelope around it (red surface), the OSL model best fit (vertical blue line) with the $68 \%$ confidence level envelope around it (blue surface) and the intersection of the two confidence surfaces (dark surface) are shown on (c). The intersection alone is represented on (d), with its 2D projection onto the axial planes (grey surfaces) and further 1D reprojection onto the axes (grey labelled lines). After Guralnik et al. (2011). (For interpretation of the references to colour in this figure legend, the reader is referred to the web version of this article.)

knowledged for their thoughtful suggestions on an earlier version of this manuscript.

David Bridgland is also acknowledged for his editorial work and for having improved the English of the manuscript.

\section{References}

Adams, K.D., Locke, W.W., Rossi, R., 1992. Obsidian-hydration dating of fluvially reworked sediments in the West Yellowstone region, Montana. Quat. Res. 38, 180-195.

Adamson, K.R., Woodward, J.C., Hughes, P.D., 2014. Glaciers and rivers: Pleistocene uncoupling in a Mediterranean mountain karst. Quat. Sci. Rev. 94, 28-43.

Aitken, M.J., 1985. Thermoluminescence Dating. Academic Press, London.

Anderson, R.S., Repka, J.L., Dick, G.S., 1996. Explicit treatment of inheritance in dating depositional surfaces using in situ ${ }^{10} \mathrm{Be}$ and ${ }^{26} \mathrm{Al}$. Geology $24,47-51$.

Anthony, D.M., Granger, D.E., 2007. A new chronology for the age of Appalachian erosional surfaces determined by cosmogenic nuclides in cave sediments. Earth Surf. Process Landforms 887, 874-887.

Antoine, P., Limondin Lozouet, N., Chaussé, C., Lautridou, J.-P., Pastre, J.-F., Auguste, P., Bahain, J.-J., Falguères, C., Galehb, B., 2007. Pleistocene fluvial terraces from northern France (Seine, Yonne, Somme): synthesis, and new results from interglacial deposits. Quat. Sci. Rev. 26 (22-24), 2701-2723.

Antón, L., Rodés, A., De Vicente, G., Pallàs, R., Garcia-Castellanos, D., Stuart, F.M., Braucher, R., Bourlès, D., 2012. Quantification of fluvial incision in the Duero Basin (NW Iberia) from longitudinal profile analysis and terrestrial cosmogenic nuclide concentrations. Geomorphology 165-166, 50-61.

Arnold, L.J., Roberts, R.G., 2009. Stochastic modelling of multi-grain equivalent dose (De) distributions: implications for OSL dating of sediment mixtures. Quat. Sci. Rev. 4, 209-230.
Arnold, L.J., Demurob, M., Parésc, J.M., Pérez-Gonzálezc, A., Arsuagad, J.L., Bermúdez de Castroc, J.M., Carbonell, E., 2015. Evaluating the suitability of extended-range luminescence dating techniques over early and Middle Pleistocene timescales: published datasets and case studies from Atapuerca, Spain. Quat. Int. 389, 167-190.

Balco, G., Rovey, C.W., 2008. An isochron method for cosmogenic-nuclide dating of buried soils and sediments. Am. J. Sci. 308, 1083-1114.

Balco, G., Shuster, D.L., 2009. ${ }^{26} \mathrm{Al}-{ }^{10} \mathrm{Be}-{ }^{21} \mathrm{Ne}$ burial dating. Earth Planet. Sci. Lett. 286, 570-575

Bartz, M., Klasen, N., Zander, A., Brill, D., Rixhon, G., Seeliger, M., Eiwanger, J., Weniger, G.-C., Mikdad, A., Brückner, H., 2015. Luminescence dating of ephemeral stream deposits around the Palaeolithic site of Ifri n'Ammar (Morocco). Quat. Geochronol. 30, 460-465.

Bates, M.R., 1994. Quaternary aminostratigraphy in Northwestern France. Quat. Sci. Rev. 12, 793-809.

Baynes, E.R.C., Attal, M., Niedermann, S., Kirstein, L.A., Dugmore, A.J., Naylor, M., 2015. Erosion during extreme flood events dominates Holocene canyon evolution in northeast Iceland. Proc. Natl. Acad. Sci. U. S. A. 112, 2355-2360

Beerten, K., Stesmans, A., 2006. Some properties of Ti-related paramagnetic centres relevant for Electron Spin Resonance dating of single sedimentary quartz grains. Appl. Radiat. Isotopes 64, 594-602.

Bird, M.I., Ayliffe, L.K., Fifield, L.K., Turney, C.M., Cresswell, R.G., Barrows, T.T. David, B., 1999. Radiocarbon dating of "old" charcoal using a wet oxidation, stepped-combustion procedure. Radiocarbon 41, 127-140.

Bischoff, J.L., Fitzpatrick, J.A., 1991. U-series dating of impure carbonates: an isochron technique using total-sample dissolution. Geochim. Cosmochim. Acta 55, 543-554

Blisniuk, K., Oskin, M., Fletcher, K., Rockwell, T., Sharp, W., 2012. Assessing the reliability of U-series and ${ }^{10} \mathrm{Be}$ dating techniques on alluvial fans in the Anza Borrego Desert, California. Quat. Geochronol. 13, 26-41. 
Blisniuk, P.M., Sharp, W.D., 2003. Rates of late Quaternary normal faulting in central Tibet from U-series dating of pedogenic carbonate in displaced fluvial gravel deposits. Earth Planet. Sci. Lett. 215, 169-186.

Bourdon, B., Henderson, G.M., Lundstrom, C.C., Turner, S.P. (Eds.), 2003. Uranium-Series Geochemistry. Mineralogical Society of America, Washington, DC.

Braucher, R., Del Castillo, P., Siame, L., Hidy, A.J., Bourlès, D.L., 2009. Determination of both exposure time and denudation rate from an in situ-produced ${ }^{10} \mathrm{Be}$ depth profile: a mathematical proof of uniqueness. Model sensitivity and applications to natural cases. Quat. Geochronol. 4, 56-67.

Brauer, A., Hajdas, I., Blockley, S.P., Ramsey, C.B., Christl, M., Ivy-Ochs, S., Moseley, G.E., Nowaczyk, N.N., Rasmussen, S.O., Roberts, H.M., Spötl, C., 2014. The importance of independent chronology in integrating records of past climate change for the 60-8 ka INTIMATE time interval. Quat. Sci. Rev. 106, 47-66.

Briant, R.M., Coope, G.R., Preece, R.C., Gibbard, P.L., 2004. Evidence for early Devensian (Weichselian) fluvial sedimentation: geochronological and palaeoenvironmental data from the upper Pleistocene deposits at Deeping St James, Lincolnshire, England. Quaternaire 15, 5-15.

Briant, R.M., Bates, M.R., Schwenninger, J.-L., Wenban-Smith, F.F., 2006. A long optically-stimulated luminescence dated Middle to Late Pleistocene fluvial sequence from the western Solent Basin, southern England. J. Quat. Sci. 21, 507-523.

Briant, R.M., Bateman, M.D., 2009. Luminescence dating indicates radiocarbon age underestimation in late Pleistocene fluvial deposits from eastern England. J. Quat. Sci. 24, 916-927.

Brock, F., Higham, T., Ditchfield, P., Bronk Ramsey, C., 2010. Current pretreatment methods for AMS Radiocarbon Dating at the Oxford Radiocarbon Accelerator Unit (ORAU). Radiocarbon 52, 103-112.

Broecker, W.S., 1963. A preliminary evaluation of uranium series inequilibrium as a tool for absolute age measurement on marine carbonates. J. Geophys. Res. 68, 2817-2834.

Brunnacker, K., Löscher, M., Tillmanns, W., Urban, B., 1982. Correlation of the Quaternary terrace sequence in the lower Rhine Valley and northern Alpine foothills of central Europe. Quat. Res. 18, 152-173.

Burbank, D.W., Leland, J., Fielding, E., Anderson, R.S., Brozovic, N., Reid, M.R., Duncan, C., 1996. Bedrock incision, rock uplift \& threshold hillslopes in NW Himalayas. Nature 379, 505-510.

Buylaert, J.P., Murray, A.S., Thomsen, K.J., Jain, M., 2009. Testing the potential of an elevated temperature IRSL signal from K-feldspar. Radiat. Meas. 44, 560-565.

Candy, I., Black, S., Sellwood, B.W., 2004. Quantifying time scales of pedogenic calcrete formation using U-series disequilibria. Sediment. Geol. 170, 177-187.

Candy, I., Black, S., Sellwood, B.W., 2005. U-series isochron dating of immature and mature calcretes as a basis for constructing Quaternary landform chronologies for the Sorbas basin, southeast Spain. Quat. Res. 64, 100-111.

Candy, I., Schreve, D., 2007. Land-sea correlation of Middle Pleistocene temperate sub-stages using high-precision uranium-series dating of tufa deposits from southern England. Quat. Sci. Rev. 26, 1223-1235.

Chaussé, C., Voinchet, P., Bahain, J.J., Connet, N., Lhomme, V., Limondin-Lozouet, N., 2004. Middle and upper Pleistocene evolution of the river Yonne valley (France). Quaternaire 15, 53-64.

Cheng, H., Edwards, R.L., Hoff, J., Gallup, C.D., Richards, D.A., Asmerom, Y., 2000. The half-lives of uranium-234 and thorium-230. Chem. Geol. 169, 17-33.

Cheng, H., Edwards, R.L., Shen, C.-C., Polyak, V.J., Asmerom, Y., Woodhead, J., Hellstrom, J., Wang, Y., Kong, X., Spötl, C., Wang, X., Alexander Jr., E.C., 2013 Improvements in ${ }^{230} \mathrm{Th}$ dating, ${ }^{230} \mathrm{Th}$ and ${ }^{234} \mathrm{U}$ half-life values, and $\mathrm{U}-\mathrm{Th}$ isotopic measurements by multi-collector inductively coupled plasma mass spectrometry. Earth Planet. Sci. Lett. 371, 82-91.

Colarossi, D., Duller, G.A.T., Roberts, H.M., Tooth, S., Lyons, R., 2015. Comparison of paired quartz OSL and feldspar post-IR IRSL dose distributions in poorly bleached fluvial sediments from South Africa. Quat. Geochronol. 30, 233-238.

Colman, S.M., Pierce, K.L., 1981. Weathering rinds on andesitic and basaltic stones as a Quaternary Age indicator, Western United States. Geol. Surv. Prof. Pap. 1210, 1-56.

Coltorti, M., Della Fazia, J., Paredes Rios, F., Tito, G., 2010. The Nuagapua alluvial fan sequence: early and Late Holocene human-induced changes in the Bolivian Chaco?. Proc. Geol. Assoc. 121, 218-228.

Cordier, S., Harmand, D., Lauer, T., Voinchet, P., Bahain, J.-J., Frechen, M., 2012. Geochronological reconstruction of the Pleistocene evolution of the Sarre valley (France and Germany) using OSL and ESR dating techniques. Geomorphology $165-166,91-106$

Cordier, S., Frechen, M., Harmand, D., 2014. Dating fluvial erosion: fluvial response to climate change in the Moselle catchment (France, Germany) since the Late Saalian. Boreas 43, 450-468.

Crook, R., 1986. Relative dating of Quaternary deposits based on P-wave velocities in weathered granitic clasts. Quat. Res. 25, 281-292.

Cunha, P.P., Almeida, N.A.C., Aubry, T., Martins, A.A., Murray, A.S., Buylaert, J.P., Sohbati, R., Raposo, L., Rocha, L., 2012. Records of human occupation from Pleistocene river terrace and aeolian sediments in the Arneiro depression (Lower Tejo River, central eastern Portugal). Geomorphology 165-166, 78-90.
Cunningham, A.C., Wallinga, J., 2010. Selection of integration time intervals for quartz OSL decay curves. Quat. Geochronol. 5, 657-666.

Cunningham, A.C., Wallinga, J., 2012. Realizing the potential of fluvial archives using robust OSL chronologies. Quat. Geochronol. 12, 98-106.

Darling, A.L., Karlstrom, K.E., Granger, D.E., Aslan, A., Kirby, E., Ouimet, W.B., Lazear, G.D., Coblentz, D.D., Cole, R.D., 2012. New incision rates along the Colorado River system based on cosmogenic burial dating of terraces: implications for regional controls on Quaternary incision. Geosphere 8, 1020-1041.

Davis, W.M., 1899. The geographical cycle. Geogr. J. 481-504.

Davis, R., Schaeffer, O.A., 1955. Chlorine-36 in nature. Ann. N. Y. Acad. Sci. $62,105-122$

Deevey Jr., E.S., Gross, M.S., Hutchinson, G.E., Kraybill, H.L., 1954. The natural C14 contents of materials from hard-water lakes. Proc. Natl. Acad. Sci. U. S. A. 40,285

de Moor, J.J.W., Kasse, C., van Balen, R., Vandenberghe, J., Wallinga, J., 2008. Human and climate impact on catchment development during the Holocene-Geul River, the Netherlands. Geomorphology 98, 316-339.

Despriée, J., Gageonnet, R., Voinchet, P., Bahain, J.J., Falguères, C., Duvialard, J., Varache, F., 2004. Pleistocene fluvial systems of the Creuse River (Middle Loire Basin - Centre Region, France). Quaternaire 15, 77-86.

Ditlefsen, C., 1992. Bleaching of K-feldspars in turbid water suspensions: a comparison of photo- and thermoluminescence signals. Quat. Sci. Rev. 11, 33-38.

Dunai, T., 2010. Cosmogenic Nuclides - Principles, Concepts and Applications in the Earth Surface Sciences. Cambridge University Press, 187

Duller, G.A.T., 2004. Luminescence dating of Quaternary sediments: recent advances. J. Quat. Sci. 19, 183-192.

Duller, G.A.T., 2008. Single-grain optical dating of Quaternary sediments: why aliquot size matters in luminescence dating. Boreas 37, 589-612.

Duval, M., 2012. Dose response curve of the ESR signal of the Aluminum center in quartz grains extracted from sediment. Anc. TL 30, 1-9.

Duval, M., 2015. In: Rink, W.J., Thompson, J.W. (Eds.), Electron Spin Resonance (ESR) Dating of Fossil Tooth Enamel. Encyclopedia of Scientific Dating Methods. Springer, Netherlands, pp. 239-246.

Duval, M., 2016. Electron Spin Resonance dating in In: Gilbert, A.S (Ed.), Encyclopedia of Geoarchaeology. Springerhttp://dx.doi.org/10.1007/ 978-1-4020-4409-0.

Duval, M., Guilarte Moreno, V., 2012. Assessing the influence of the cavity temperature on the ESR signal of the Aluminum center in quartz grains extracted from sediment. Anc. TL 30, 11-16.

Duval, M., Guilarte, V., 201z. ESR dosimetry of optically bleached quartz grains extracted from Plio-Quaternary sediment: evaluating some key aspects of the ESR signals associated to the Ti-centers. Radiat. Meas. 78, 28-41.

Duval, M., Sancho, C., Calle, M., Guilarte, V., Peña-Monné, J.L., 2015. On the interest of using the multiple center approach in ESR dating of optically bleached quartz grains: some examples from the Early Pleistocene terraces of the Alcanadre River (Ebro basin, Spain). Quat. Geochronol. 29, 58-69.

Edwards, R.L., Chen, J.H., Wasserburg, G.J., 1987. ${ }^{238} \mathrm{U}_{-}{ }^{234} \mathrm{U}_{-}{ }^{230} \mathrm{Th}^{2}{ }^{232} \mathrm{Th}$ systematics and the precise measurement of time over the past 500,000 years. Earth Planet. Sci. Lett. 81, 175-192.

Edwards, R.L., Gallup, C.D., Cheng, H., 2003. Uranium-series dating of marine and lacustrine carbonates. In: Bourdon, B., Henderson, G.M., Lundstrom, C.C., Turner, S.P. (Eds.), Uranium-Series Geochemistry. Mineralogical Society of America, Washington, DC.

Eggins, S.M., Grün, R., McCulloch, M.T., Pike, A.W.G., Chappell, J., Kinsley, L., Mortimer, G., Shelley, M., Murray-Wallace, C.V., Spötl, C., Taylor, L., 2005. In situ U-series dating by laser-ablation multi-collector ICPMS: new prospects for Quaternary geochronology. Quat. Sci. Rev. 24, 2523-2538.

Engel, S.A., Gardner, T.W., Ciolkosz, E.J., 1996. Quaternary soil chronosequences on terraces of the Susquehanna River, Pennsylvania. Geomorphology 17, 273-294.

Erlanger, E.D., Granger, D.E., Gibbon, R.J., 2012. Rock uplift rates in South Africa from isochron burial dating of fluvial and marine terraces. Geology 40, 1019-1022.

Falguères, C., Bahain, J.-J., Pérez-González, A., Mercier, N., Santonja, M., Dolo, J.-M., 2006. The Lower Acheulian site of Ambrona, Soria (Spain): ages derived from a combined ESR/U-series model. J. Archaeol. Sci. 33, 149-157.

Flez, C., Lahousse, P., 2015. Example of Holocene alpine torrent response to environmental change: contribution to assessment of forcing factors. Quaternaire $15,167-176$

Fontana, A., Mozzi, P., Bondesan, A., 2008. Alluvial megafans in the Venetian-Friulian plain (north-eastern Italy): evidence of sedimentary and erosive phases during late Pleistocene and holocene. Quat. Int. 189, 71-90.

Fuchs, M.C., Kreutzer, S., Burow, C., Dietze, M., Fischer, M., Schmidt, C., Fuchs, M., 2015. Data processing in luminescence dating analysis: an exemplary workflow using the R package 'Luminescence'. Quat. Int. 362, 8-13.

Galbraith, R.F., 2010. On plotting OSL equivalent dose estimates. Anc. TL 28, 1-9.

Galbraith, R.F., Green, P.F., 1990. Estimating the component ages in a finite mixture. Nucl. Tracks Radiat. Meas. 17, 197-206. 
Galbraith, R.F., Laslett, G.M., 1993. Statistical models for mixed fission track ages. Nucl. Tracks Radiat. Meas. 21. 495-470.

Galbraith, R.F., Roberts, R.G., 2012. Statistical aspects of equivalent dose and error calculation and display in OSL dating: an overview and some recommendations. Quat. Geochronol. 11, 1-27.

Garnier, A., Lespez, L., Ozainne, S., Ballouche, A., Mayor, A., Le Drézen, Y., Rasse, M., Huysecom, E., 2015. L'incision généralisée de la vallée du Yamé (Mali) entre 2350 et 1700 ans cal. BP : quelle signification paléoenvironnementale et archéologique?. Quaternaire 26, 49-66.

Geach, M.R., Thomsen, K.J., Buylaert, J.-P., Murray, A.S., Mather, A.E., Telfer, M.W., Stokes, M., 2015. Single-grain and multi-grain OSL dating of river terrace sediments in the Tabernas Basin, SE Spain. Quat. Geochronol. 30, 213-218.

Godwin, H., 1962. Half-life of radiocarbon. Nature 195.

Goldstein, S.J., Stirling, C.H., 2003. Techniques for measuring Uranium-series nuclides: 1992-2002. In: Bourdon, B., Henderson, G.M., Lundstrom, C.C., Turner, S.P. (Eds.), Uranium-Series Geochemistry. Mineralogical Society of America, Washington, DC.

Gosse, J.C., Phillips, F.M., 2001. Terrestrial in situ cosmogenic nuclides: theory and application. Quat. Sci. Rev. 20, 1475-1560.

Gorter, S.C., 1936. Paramagnetic relaxation in a transversal magnetic field. Physica 3, 1006-1008.

Granger, D.E., Kirchner, J.W., Finkel, R.C., 1997. Quaternary downcutting rate of the New River, Virginia, measured from differential decay of cosmogenic ${ }^{26} \mathrm{Al}$ and ${ }^{10} \mathrm{Be}$ in cave-deposited alluvium. Geology $25,107-110$.

Granger, D.E., Muzikar, P.F., 2001. Dating sediment burial with in situ-produced cosmogenic nuclides: theory, techniques, and limitations. Earth Planet. Sci. Lett. 188, 269-281.

Granger, D.E., 2014. Cosmogenic Nuclide burial dating in archaeology and Paleoanthropology. In: Treatise on Geochemistry, second ed. Elsevier Ltd., pp. 81-97.

Grün, R., 1989. Electron Spin Resonance (ESR) dating. Quat. Int. 1, 65-109.

Griin, R., 2000. An alternative model for open system $U$-series/ESR age caleulations: (elosed system U series) ESR, CSUS ESR. Ane. TL 18(1), 14.

Grün, R., 2009. The relevance of parametric U-uptake models in ESR age calculations. Radiat. Meas. 44 (5-6), 472-476.

Grün, R., Schwarcz, H.P., Chadam, J., 1988. ESR dating of tooth enamel: coupled correction for U-uptake and U-series disequilibrium. Nucl. Tracks Radiat. Meas. 14, 237-241.

Guerin, G., Combès, B., Lahaye, C., Thomsen, K.J., Tribolo, C., Urbanova, P., Guibert, P., Mercier, N., Valladas, H., 2015. Testing the accuracy of a Bayesian central-dose model for single-grain OSL, using known-age samples. Radiat. Meas. 81, 62-70.

Guilarte, V., Trompier, F., Duval, M., 2016. Evaluating the potential of Q-band ESR spectroscopy for dose reconstruction of fossil tooth enamel. PLoS One 11 (3), e0150346. http://dx.doi.org/10.1371/journal.pone.0150346.

Guralnik, B., Matmon, A., Avni, Y., Porat, N., Fink, D., 2011. Constraining the evolution of river terraces with integrated OSL and cosmogenic nuclide data. Quat. Geochronol. 6, 22-32.

Harmand, D., Voinchet, P., Cordier, S., Bahain, J., Rixhon, G., 2015. Datations ESR de terrasses alluviales des vallées de la Moselle et de la Meurthe (France, Allemagne): implications chronostratigraphiques et limites méthodologiques. Quaternaire 13-26.

Häuselmann, P., Granger, D.E., Jeannin, P.-Y., Lauritzen, S.-E., 2007. Abrupt glacial valley incision at $0.8 \mathrm{Ma}$ dated from cave deposits in Switzerland. Geology $35,143-146$.

Hellstrom, J.C., 2006. U-Th dating of speleothems with high initial ${ }^{230} \mathrm{Th}$ using stratigraphical constraint. Quat. Geochronol. 1, 289-295.

Hidy, A.J., Gosse, J.C., Pederson, J.L., Mattern, J.P., Finkel, R.C., 2010. A geologically constrained Monte Carlo approach to modeling exposure ages from profiles of cosmogenic nuclides: an example from Lees Ferry, Arizona. Geochem. Geophys. Geosystems 11

Higham, T.F., Jacobi, R.M., Ramsey, C.B., 2006. AMS radiocarbon dating of ancient bone using ultrafiltration. Radiocarbon $48,179$.

Hippe, K., Kober, F., Zeilinger, G., Ivy-Ochs, S., Maden, C., Wacker, L., Kubik, P.W., Wieler, R., 2012. Quantifying denudation rates and sediment storage on the eastern Altiplano, Bolivia, using cosmogenic ${ }^{10} \mathrm{Be},{ }^{26} \mathrm{Al}$, and in situ ${ }^{14} \mathrm{C}$. Geomorphology $179,58-70$.

Hogg, A.G., Hua, Q., Blackwell, P.G., Niu, M., Buck, C.E., Guilderson, T.P., Heaton, T.J., Palmer, J.G., Reimer, P.J., Reimer, R.W., Turney, C.S., 2013. SHCal13 Southern Hemisphere calibration, 0-50,000 years cal BP. Radiocarbon $55,1889-1903$.

Huntley, D.J., Godfrey-Smith, D.I., Thewalt, M.L., 1985. Optical dating of sediments. Nature 313, 105-107.

Huntley, D.J., Lamothe, M., 2001. Ubiquity of anomalous fading in K-feldspars and the measurement and correction for it in optical dating. Can. J. Earth Sci. 38, 1093-1106.

Ikeya, M., 1975. Dating a stalactite by electron paramagnetic resonance. Nature $255,48-50$.
Ikeya, M., 1993. New Applications of Electron Spin Resonance: Dating, Dosimetry and Microscopy. World Scientific, Singapore.

Ivanovich, M., Harmon, R.S. (Eds.), 1992. Uranium-Series Disequilibrium: Applications to Earth, Marine, and Environmental Sciences. Oxford University Press.

Ivy-Ochs, S., Kober, F., 2008. Surface exposure dating with cosmogenic nuclides. Eiszeitalt. Ggw. Quat. Sci. J. 57, 179-209.

Jacobson, R.B., Elston, D.P., Heaton, J.W., 1988. Stratigraphy and magnetic polarity of the high terrace remnants in the upper Ohio and Monongahela rivers in West Virginia, Pennsylvania and Ohio. Quat. Res. 29, 216-232.

Jain, M., Murray, A.S., Botter-Jensen, L., 2004. Optically stimulated luminescence dating: how significant is incomplete light exposure in fluvial environments?. Quaternaire $15,143-157$.

Jain, M., Murray, A.S., Bøtter-Jensen, L., Wintle, A.G., 2005. A single-aliquot regenerative-dose method based on IR bleaching of the fast OSL component in quartz. Radiat. Meas. 39, 309-318.

Joannes-Boyau, R., Grün, R., 2011. A comprehensive model for $\mathrm{CO}_{2}{ }^{-}$radicals in fossil tooth enamel: implications for ESR dating. Quat. Geochronol. 6, 82-97.

Kalicki, T., Sauchyk, S., Calderoni, G., Simakova, G., 2008. Climatic versus human impact on the Holocene sedimentation in river valleys of different order: examples from the upper Dnieper basin. Belarus. Quat. Int. 189, 91-105.

Kasse, C., Bohncke, S.J.P., Vandenberghe, J., 1995. Fluvial periglacial environments, climate and vegetation during the Middle Weichselian in the Northern Netherlands with special reference to the Hengelo Interstadial. Meded. Rijks Geol. Dienst 52, 387-414.

Kasse, C., Bohncke, S.J.P., Vandenberghe, J., Gábris, G., 2010. Fluvial style changes during the last glacial-interglacial transition in the middle Tisza valley (Hungary). Proc. Geol. Assoc. 121, 180-194.

Kaufman, A., 1993. An evaluation of several methods for determining ${ }^{230} \mathrm{Th} / \mathrm{U}$ ages in impure carbonates. Geochim. Cosmochim. Acta 57, 2303-2317.

Kaufman, A., Broecker, W., 1965. Comparison of ${ }^{230}$ Th and ${ }^{14} \mathrm{C}$ ages for carbonate materials from lakes Lahontan and Bonneville. J. Geophys. Res. 70, 4039-4054.

Keen-Zebert, A., Tooth, S., Rodnight, H., Duller, G.A.T., Roberts, H.M., Grenfell, M., 2013. Late Quaternary floodplain reworking and the preservation of alluvial sedimentary archives in unconfined and confined river valleys in the eastern interior of South Africa. Geomorphology 185, 54-66.

Kelly, M., Black, S., Rowan, J.S., 2000. A calcrete-based U/Th chronology for landform evolution in the Sorbas basin, southeast Spain. Quat. Sci. Rev. 19, 995-1010.

Klein, J., Middleton, R., Tang, H., 1982. Modifications of an FN tandem for quantitative ${ }^{10}$ Be Measurement. Nucl. Instrum. Methods Phys. Res. 193, 601-616.

Knuepfer, P., 1988. Estimating ages of late Quaternary stream terraces from analysis of weathering rinds and soils. Geol. Soc. Am. Bull. 100, 1224-1236.

Kock, S., Kramers, J.D., Preusser, F., Wetzel, A., 2009. Dating of Late Pleistocene terrace deposits of the River Rhine using Uranium series and luminescence methods: potential and limitations. Quat. Geochronol. 4, 363-373.

Kong, P., Granger, D.E., Wu, F.Y., Caffee, M.W., Wang, Y.J., Zhao, X.T., Zheng, Y., 2009. Cosmogenic nuclide burial ages and provenance of the Xigeda paleo-lake: implications for evolution of the Middle Yangtze River. Earth Planet. Sci. Lett. 278, 131-141.

Kreutzer, S., Schmidt, C., Fuchs, M.C., Dietze, M., Fischer, M., Fuchs, M., 2012. Introducing an R package for luminescence dating analysis. Anc. TL 30, 1-8.

Ku, T.-L., Liang, Z.-C., 1984. The dating of impure carbonates with decay-series isotopes. Nucl. Instrum. Methods Phys. Res. 223, 563-571.

Kuzucuoglu, C., Fontugne, M., Mouralis, D., 2004. Holocene terraces in the middle Euphrates valley, between Halfeti and Karkemish (Gaziantep, Turkey). Quaternaire $15,195-206$.

Lauer, T., Frechen, M., Hoselmann, C., Tsukamoto, S., 2010. Fluvial aggradation phases in the Upper Rhine Graben-new insights by quartz OSL dating. Proc. Geol. Assoc. 121, 154-161.

Le Dortz, K., Meyer, B., Sébrier, M., Braucher, R., Nazari, H., Benedetti, L., Fattahi, M., Bourlès, D., Foroutan, M., Siame, L., Rashidi, A., Bateman, M.D., 2011. Dating inset terraces and offset fans along the Dehshir Fault (Iran) combining cosmogenic and OSL methods. Geophys. J. Int. 185, 1147-1174.

Leland, J., Reid, M.R., Burbank, D.W., Finkel, R., Caffee, M., 1998. Incision and dif ferential bedrock uplift along the Indus River near Nanga Parbat, Pakistan Himalaya, from ${ }^{10} \mathrm{Be}$ and ${ }^{26} \mathrm{Al}$ exposure age dating of bedrock straths. Earth Planet. Sci. Lett. 154, 93-107.

Lewin, J., Macklin, M.G., 2003. Preservation potential for Late Quaternary river alluvium. J. Quat. Sci. 18, 107-120.

Lewin, J., Macklin, M.G., Johnstone, E., 2005. Interpreting alluvial archives: sedimentological factors in the British Holocene fluvial record. Quat. Sci. Rev. 24, 1873-1889.

Libby, W.F., Anderson, E.C., Arnold, J.R., 1949. Age determination by radiocarbon content: world-wide assay of natural radiocarbon. Science 109, 227-228.

Liu, C.-R., Grün, R., 2011. Fluvio-mechanical resetting of the Al and Ti centres in quartz. Radiat. Meas. 46 (10), 1038-1042.

Ludwig, K.R., 2003. Mathematical-statistical treatment of data and errors for $230 \mathrm{Th} / \mathrm{U}$ geochronology. In: Bourdon, B., Henderson, G.M., Lundstrom, C.C., Turner, S.P. 
(Eds.), Uranium-Series Geochemistry. Mineralogical Society of America, Washington, DC.

Ludwig, K.R., Paces, J.B., 2002. Uranium-series dating of pedogenic silica and carbonate, Crater Flat, Nevada. Geochim. Cosmochim. Acta 66, 487-506.

Luo, S., Ku, T.-L., 1991. U-series isochron dating: a generalized method employing total-sample dissolution. Geochim. Cosmochim. Acta 55, 555-564.

Macklin, M.G., Johnstone, E., Lewin, J., 2005. Pervasive and long-term forcing of Holocene river instability and flooding in Great Britain by centennial-scale climate change. Holocene 15, 937-943.

Macklin, M.G., Jones, A.F., Lewin, J., 2010. River response to rapid Holocene environmental change: evidence and explanation in British catchments. Quat. Sci. Rev. 29, 1555-1576.

Macklin, M.G., Lewin, J., 2003. River sediments, great floods and centennial-scale Holocene climate change. J. Quat. Sci. 18, 101-105.

Martin, L., Incerti, S., Mercier, N., 2015. DosiVox: Implementing Geant 4-based software for dosimetry simulations relevant to luminescence and ESR dating techniques. Anc. TL 33, 1-10.

Martins, A.A., Cunha, P.P., Rosina, P., Osterbeek, L., Cura, S., Grimaldi, S., Gomes, J., Buylaert, J.P., Murray, A.S., Matos, J., 2010. Geoarchaeology of Pleistocene open-air sites in the Vila Nova da Barquinha-Santa Cita area (Lower Tejo River basin, central Portugal). Proc. Geol. Assoc. 121, 128-140.

Mathieu, J., Weisrock, A., Wengler, L., Brochier, J.E., Even, G., Fontugne, M., Mercier, N., Ouammou, A., Sénégas, F., Valladas, H., Vernet, J.L., Wahl, L., 2015. Holocene deposits in the lower section of the Assaka Wadi, South Morocco: preliminary results. Quaternaire 15, 207-218.

Mertz-Kraus, R., Jochum, K.P., Sharp, W.D., Stoll, B., Weis, U., Andreae, M.O., 2010. In situ ${ }^{230} \mathrm{Th}^{-232} \mathrm{Th}^{234}{ }^{23-}{ }^{238} \mathrm{U}$ analysis of silicate glasses and carbonates using laser ablation single-collector sector-field ICP-MS. J. Anal. Atomic Spectrom. 25, 1895-1904.

Millard, A., 2014. Conventions for reporting radiocarbon determinations. Radiocarbon $56,555-559$.

Mol, J., Roebroeks, W., Kamermans, H., van Kolfschoten, T., Turq, A., 2004. Weichselian and holocene fluvial evolution of the Vézère river valley (Dordogne, France). Quaternaire 15, 187-193.

Murray, A.S., Olley, J.M., 2002. Precision and accuracy in the optically stimulated luminescence dating of sedimentary quartz: a status review. Geochronometria $21,1-16$

Murray, A.S., Wintle, A.G., 2000. Luminescence dating of quartz using an improved single-aliquot regenerative-dose protocol. Radiat. Meas. 32, 57-73.

Murray, A.S., Wintle, A.G., 2003. The single aliquot regenerative dose protocol: potential for improvements in reliability. Radiat. Meas. 37, 377-381.

Nishiizumi, K., Lal, D., Klein, J., Middleton, R., Arnold, J., 1986. Production of ${ }^{10} \mathrm{Be}$ and ${ }^{26} \mathrm{Al}$ by cosmic rays in terrestrial quartz in situ and implications for erosion rates. Nature $319,134-136$.

Owen, L.A., Clemmens, S.J., Finkel, R.C., Gray, H., 2014. Late Quaternary alluvial fans at the eastern end of the San Bernardino mountains, Southern California. Quat. Sci. Rev. 87, 114-134.

Penkman, K.E.H., Preece, R.C., Keen, D.H., Maddy, D., Schreve, D.C., Collins, M.J., 2007. Testing the aminostratigraphy of fluvial archives: the evidence from intra-crystalline proteins within freshwater shells. Quat. Sci. Rev. 26, 2958-2969.

Philippsen, B., 2013. The freshwater reservoir effect in radiocarbon dating. Herit. Sci. $1,24$.

Pigati, J.S., Quade, J., Wilson, J., Jull, A.T., Lifton, N.A., 2007. Development of low-background vacuum extraction and graphitization systems for ${ }^{14} \mathrm{C}$ dating of old (40-60 ka) samples. Quat. Int. 166, 4-14.

Preece, R.C., 1999. Mollusca from last interglacial fluvial deposits of the river Thames at Trafalgar Square, London. J. Quat. Sci. 14, 77-89.

Preusser, F., Chithambo, M.L., Götte, T., Martini, M., Ramseyer, K., Sendezera, E.J., Susino, G.J., Wintle, A.G., 2009. Quartz as a natural luminescence dosimeter. Earth Sci. Rev. 97, 184-214.

Rades, E.F., Hetzel, R., Xu, Q., Ding, L., 2013. Constraining Holocene lake-level highstands on the tibetan plateau by ${ }^{10} \mathrm{Be}$ exposure dating: a case study at Tangra Yumco, southern Tibet. Quat. Sci. Rev. 82, 68-77.

Ramos, A.M., Cunha, P.P., Cunha, L.S., Gomes, A., Lopes, F.C., Buylaert, J.P., Murray, A.S., 2012. The River Mondego terraces at the Figueira da Foz coastal area (western central Portugal): geomorphological and sedimentological characterization of a terrace staircase affected by differential uplift and glacio-eustasy. Geomorphology 165-166, 107-123.

Reimer, P.J., Baillie, M.G., Bard, E., Bayliss, A., Beck, J.W., Bertrand, C.J., Blackwell, P.G., Buck, C.E., Burr, G.S., Cutler, K.B., Damon, P.E., 2004. IntCal04 terrestrial radiocarbon age calibration, 0-26 cal kyr BP. Radiocarbon 46, 1029-1058.

Reimer, P.J., Bard, E., Bayliss, A., Beck, J.W., Blackwell, P.G., Bronk Ramsey, C., Buck, C.E., Cheng, H., Edwards, R.L., Friedrich, M., Grootes, P.M., 2013. IntCal13 and Marine13 Radiocarbon age Calibration Curves 0-50,000 Years cal BP. Radiocarbon 55, 1869-1887.

Repka, J.L., Anderson, R.S., Finkel, R.C., 1997. Cosmogenic dating of fluvial terraces, Fremont River, Utah. Earth Planet. Sci. Lett. 152, 59-73.
Reusser, L., Bierman, P., Pavich, M., Larsen, J., Finkel, R., 2006. An episode of rapid bedrock channel incision during the last glacial cycle, measured with ${ }^{10} \mathrm{Be}$. Am. J. Sci. 306, 69-102

Richards, D.A., Dorale, J.A., 2003. Uranium-series chronology and environmental applications of speleothems. In: Bourdon, B., Henderson, G.M., Lundstrom, C.C. Turner, S.P. (Eds.), Uranium-Series Geochemistry. Mineralogical Society of America, Washington, DC.

Rink, W.J., Bartoll, J., Schwarcz, H.P., Shane, P., Bar-Yosef, O., 2007. Testing the reliability of ESR dating of optically exposed buried quartz sediments. Radiat. Meas. 42, 1618-1626.

Rittenour, T.M., 2008. Luminescence dating of fluvial deposits: applications to geomorphic, palaeoseismic and archaeological research. Boreas 37, 613-635.

Rixhon, G., Braucher, R., Bourlès, D., Siame, L., Bovy, B., Demoulin, A., 2011. Quaternary river incision in NE Ardennes (Belgium) - insights from ${ }^{10} \mathrm{Be} /{ }^{26} \mathrm{Al}$ dating of river terraces. Quat. Geochronol. 6, 273-284.

Rixhon, G., Bourlès, D.L., Braucher, R., Siame, L., Cordy, J.M., Demoulin, A., 2014. ${ }^{10} \mathrm{Be}$ dating of the Main Terrace level in the Amblève valley (Ardennes, Belgium): new age constraint on the archaeological and palaeontological filling of the Belle-Roche palaeokarst. Boreas 43, 528-542.

Rodnight, H., 2008. How many equivalent dose values are needed to obtain a reproducible distribution?. Anc. TL 26, 3-10.

Rogerson, R.J., Keen, D.H., Coope, G.R., Robinson, E., Dickson, J.H., Dickson, C.A 1992. The fauna, flora and palaeoenvironmental significance of deposits beneath the low terrace of the River Great Ouse at Radwell, Bedfordshire, England. Proc. Geol. Assoc. 103, 1-13.

Roy-Barman, M., Pons-Branchu, E., 2016. Improved U-Th dating of carbonates with high initial ${ }^{230}$ Th using stratigraphical and coevality constraints. Quat. Geochronol. 32, 29-39.

Ruff, M., Szidat, S., Gäggeler, H.W., Suter, M., Synal, H.A., Wacker, L., 2010. Gaseous radiocarbon measurements of small samples. Nucl. Instrum. Methods Phys. Res. Sect. B Beam Interact. Mater. Atoms 268, 790-794.

Salvador, P.G., Berger, J.F., Gauthier, E., Vanniere, B., 2004. Holocene fluctuations of the Rhône River in the alluvial plain of the basses Terres (Isère, Ain, France). Quaternaire $15,177-186$.

Sanderson, D.C.W., Murphy, W., 2010. Using simple portable OSL measurements and laboratory characterisation to help understand complex and heterogeneous sediment sequences for luminescence dating. Quat. Geochronol. 5, 299-305.

Santonja, M., Pérez-González, A., Domínguez-Rodrigo, M., Panera, J., Rubio-Jara, S., Sesé, C., Soto, E., Arnold, L.J., Duval, M., Demuro, M., Ortiz, J.E., de Torres, T., Mercier, N., Barba, R., Yravedra, J., 2014. The Middle Paleolithic site of Cuesta de la Bajada (Teruel, Spain): a perspective on the Acheulean and Middle Paleolithic technocomplexes in Europe. J. Archaeol. Sci. 49, 556-571.

Schaefer, J.M., Faestermann, T., Herzog, G.F., Knie, K., Korschinek, G., Masarik, J., Meier, A., Poutivtsev, M., Rugel, G., Schlüchter, C., Serifiddin, F., Winckler, G., 2006. Terrestrial manganese-53-A new monitor of Earth surface processes. Earth Planet. Sci. Lett. 251, 334-345.

Scherbina, O.I., Brik, A.B., 2000. Temperature stability of carbonate groups in tooth enamel. Appl. Radiat. Isotopes 52, 1071-1075.

Schmidt, C., Kreutzer, S., DeWitt, R., Fuchs, M., 2015. Radiofluorescence of quartz : a review. Quat. Geochronol. 27, 66-77.

Schmidt, S., Hetzel, R., Kuhlmann, J., Mingorance, F., Ramos, V.A., 2011. A note of caution on the use of boulders for exposure dating of depositional surfaces. Earth Planet. Sci. Lett. 302, 60-70.

Scholz, D., Hoffmann, D.L., 2008. ${ }^{230} \mathrm{Th} / \mathrm{U}$-dating of fossil reef corals and speleothems. Eiszeitalt. Ggw. Quat. Sci. J. 57, 52-77.

Schramm, A., Stein, M., Goldstein, S.L., 2000. Calibration of the ${ }^{14} \mathrm{C}$ time scale to $>40$ ka by ${ }^{234} \mathrm{U}_{-}{ }^{230} \mathrm{Th}$ dating of Lake Lisan sediments (last glacial Dead Sea). Earth Planet. Sci. Lett. 175, 27-40.

Schreve, D.C., 2001. Differentiation of the British late Middle Pleistocene interglacials: the evidence from mammalian biostratigraphy. Quat. Sci Rev. 20, 1693-1705.

Schreve, D.C., Keen, D.H., Limondin-Lozouet, N., Auguste, P., Santistebane, J.I., Ubilla, M., Matoshko, A., Bridgland, D.R., Westaway, R., 2007. Progress in faunal correlation of Late Cenozoic fluvial sequences 2000-4: the report of the IGCP 449 biostratigraphy subgroup. Quat. Sci. Rev. 26, 2970-2995.

Schulte, L., Julià, R., Burjachs, F., Hilgers, A., 2008. Middle Pleistocene to Holocene geochronology of the River Aguas terrace sequence (Iberian Peninsula): fluvial response to Mediterranean environmental change. Geomorphology 98, 13-33.

Schwarcz, H.P., 1989. Uranium series dating of Quaternary deposits. Quat. Int. $1,7-17$.

Schwarcz, H.P., Latham, A.G., 1989. Dirty calcites 1. Uranium-series dating of contaminated calcite using leachates alone. Chem. Geol. 80, 35-43.

Sharp, W.D., Ludwig, K.R., Chadwick, O.A., Amundson, R., Glaser, L.L., 2003. Dating fluvial terraces by ${ }^{230} \mathrm{Th} / \mathrm{U}$ on pedogenic carbonate, Wind River Basin, Wyoming. Quat. Res. 59, 139-150.

Siame, L.L., Bourlès, D.L., Sébrier, M., Bellier, O., Carlos Castano, J., Araujo, M., Perez, M., Raisbeck, G.M., Yiou, F., 1997. Cosmogenic dating ranging from 20 to 
$700 \mathrm{ka}$ of a series of alluvial fan surfaces affected by the El Tigre fault, Argentina. Geology 25, 975-978.

Singareya, J.S., Bailey, R.M., 2004. Component-resolved bleaching spectra of quartz optically stimulated luminescence: preliminary results and implications for dating. Radiat. Meas. 38, 111-118.

Stock, G.M., Anderson, R.S., Finkel, R.C., 2004. Pace of landscape evolution in the Sierra Nevada, California, revealed by cosmogenic dating of cave sediments. Geology 32, 193-196.

Stokes, S., Bray, H.E., Blum, M.D., 2001. Optical resetting in large drainage basins: tests of zeroing assumptions using single-aliquot procedures. Quat. Sci. Rev. 20, 879-885.

Stone, A.E.C., Bateman, M.D., Thomas, D.S.G., 2015. Rapid age assessment in the Namib Sand Sea using a portable luminescence reader. Quat. Geochronol. 30, 134-140.

Stuiver, M., Polach, H.A., 1977. Discussion; reporting of C-14 data. Radiocarbon $19,355-363$.

Thomsen, K.J., Murray, A.S., Jain, M., Bøtter-Jensen, L., 2008. Laboratory fading rates of various luminescence signals from feldspar-rich sediment extracts. Radiat. Meas. 43, 1474-1486.

Thomsen, K.J., Murray, A.S., Jain, M., 2012. The dose dependency of the overdispersion of quartz OSL single grain dose distributions. Radiat. Meas. 47, 732-739.

Tissoux, H., Falguères, C., Voinchet, P., Toyoda, S., Bahain, J.-J., Despriée, J., 2007. Potential use of Ti-center in ESR dating of fluvial sediment. Quat. Geochronol. 2, 367-372.

Tissoux, H., 2015. In: Rink, J.W., Thompson, J. (Eds.), Sediment, ESR. Encyclopedia of Scientific Dating Methods. Springer Netherlands, Dordrecht, pp. 743-747.

Torfstein, A., Goldstein, S.L., Kagan, E.J., Stein, M., 2013. Integrated multi-site U-Th chronology of the last glacial Lake Lisan. Geochim. Cosmochim. Acta 104, 210-231.

Toyoda, S., Voinchet, P., Falguères, C., Dolo, J.M., Laurent, M., 2000. Bleaching of ESR signals by the sunlight: a laboratory experiment for establishing the ESR dating of sediments. Appl. Radiat. Isotopes 52, 1357-1362.

Toyoda, S., 2015. Paramagnetic lattice defects in quartz for applications to ESR dating. Quat. Geochronol. 30, 498-505.

Turney, C.S., Coope, G.R., Harkness, D.D., Lowe, J.J., Walker, M.J., 2000. Implications for the dating of Wisconsinan (Weichselian) Late-Glacial events of systematic radiocarbon age differences between terrestrial plant macrofossils from a site in SW Ireland. Quat. Res. 53, 114-121.

Vandenberghe, J., Gracheva, R., Sorokin, A., 2010. Postglacial floodplain development and Mesolithic-Neolithic occupation in the Russian forest zone. Proc. Geol. Assoc. 121, 229-237.

van der Schriek, T., Passmore, D.G., Franco Mugica, F., Stevenson, A.C., Boomer, I., Rolao, J., 2008. Holocene palaeoecology and floodplain evolution of the Muge tributary, Lower Tagus Basin, Portugal. Quat. Int. 189, 135-151.

Van der Woerd, J., Ryerson, F.J., Tapponnier, P., Gaudemer, Y., Finkel, R., Meriaux, A.S., Caffee, M., 1998. Holocene left-slip rate determined by cosmogenic surface dating on the Xidatan segment of the K'unlun fault (Qinghai, China). Geology 26, 695-698.

Veldkamp, A., Kroonenberg, S., Heijnis, H., Ven den Berg van Saparoea, R., 2004. The suitability of dated travertines as a record of fluvial incision: Allier (France) floodplain dynamics during the late Quaternary. Quaternaire 15, 159-165.
Vis, G.J., Kasse, C., Kroon, D., Jung, S., Zuur, H., Prick, A., 2010. Late Holocene sedimentary changes in floodplain and shelf environments of the Tagus River (Portugal). Proc. Geol. Assoc. 121, 203-217.

Voinchet, P., Bahain, J.J., Falguères, C., Laurent, M., Dolo, J.M., Despriée, J., Gageonnet, R., Chaussé, C., 2004. ESR dating of quartz extracted from Quaternary sediments application to fluvial terraces system of northern France. Quaternaire $15,135-141$

Voinchet, P., Falguères, C., Tissoux, H., Bahain, J.-J., Despriée, J., Pirouelle, F., 2007. ESR dating of fluvial quartz: estimate of the minimal distance transport required for getting a maximum optical bleaching. Quat. Geochronol. 2, 363-366.

Voinchet, P., Toyoda, S., Falguères, C., Hernandez, M., Tissoux, H., Moreno, D., Bahain, J.J., 2015. Evaluation of ESR residual dose in quartz modern samples, an investigation on environmental dependence. Quat. Geochronol. 30, 506-512.

Wallinga, J., 2002. Optically stimulated luminescence dating of fluvial deposits: a review. Boreas 31, 303-322.

Wallinga, J., Murray, A.S., Duller, G.A., Törnqvist, T.E., 2001. Testing optically stimulated luminescence dating of sand-sized quartz and feldspar from fluvial deposits. Earth Planet. Sci. Lett. 193, 617-630.

Wang, X.L., Lu, Y.C., Wintle, A.G., 2006. Recuperated OSL dating of fine-grained quartz in Chinese loess. Quat. Geochronol. 1, 89-100.

Wang, X., Van Balen, R., Yi, S., Vandenberghe, J., Lu, H., 2014. Differential tectonic movements in the confluence area of the Huang Shui and Huang He rivers (Yellow River), NE Tibetan Plateau, as inferred from fluvial terrace positions. Boreas 43, 469-484.

Wedepohl, H.K., 1995. The composition of the continental crust. Geochim. Cosmochim. Acta 59, 1217-1232.

Wenz, S., Scholz, D., Sürmelihindi, G., Passchier, C.W., Jochum, K.P., Andreae, M.O., 2016. ${ }^{230} \mathrm{Th} / \mathrm{U}$-dating of carbonate deposits from ancient aqueducts. Quat. Geochronol. 32, 40-52.

Wintle, A.G., 1973. Anomalous fading of thermoluminescence in mineral samples. Nature $245,143-144$

Wintle, A.G., Murray, A.S., 2006. A review of quartz optically stimulated luminescence characteristics and their relevance in single-aliquot regeneration dating protocols. Radiat. Meas. 41, 369-391.

Wolf, D., Seim, A., Faust, D., 2014. Fluvial system response to external forcing and human impact - Late Pleistocene and Holocene fluvial dynamics of the lower Guadalete River in western Andalucía (Spain). Boreas 43, 422-449.

Yang, Q., Scholz, D., Jochum, K.P., Hoffmann, D.L., Stoll, B., Weis, U., Schwager, B., Andreae, M.O., 2015. Lead isotope variability in speleothems - a promising new proxy for hydrological change? First results from a stalagmite from western Germany. Chem. Geol. 396, 143-151.

Zermano, P., Kurdyla, D.K., Buchoilz, B.A., Heller, S.J., Kashgarian, M., Frantz, B.R., 2004. Prevention and removal of elevated radiocarbon contamination in the LLNL/ CAMS natural radiocarbon sample preparation laboratory. Nucl. Instrum. Methods Phys. Res. B 223-224, 293-297.

Zielhofer, C., Faust, D., 2008. Mid- and Late-Holocene fluvial chronology of Tunisia. Quat. Sci. Rev. 27, 580-588.

Zhu, S., Wu, Z., Zhao, X., Li, J., Xiao, K., 2014. Ages and genesis of terrace flights in the middle reaches of the Yarlung Zangbo River, Tibetan plateau, China. Boreas 43, 485-504. 